\title{
Value added utilization of by-product electric furnace ferronickel slag as construction materials: A review
}

\author{
Ashish Kumer Saha ${ }^{1 *}$, M. N. N. Khan ${ }^{1}$, Prabir Kumar Sarker ${ }^{2}$ \\ ${ }^{1} \mathrm{PhD}$ student, School of Civil and Mechanical Engineering, Curtin University, GPO Box \\ U1987, Perth, WA 6845, Australia. \\ ${ }^{2}$ Associate Professor, School of Civil and Mechanical, Curtin University, GPO Box U1987, \\ Perth, WA 6845, Australia. \\ *Corresponding author: Email: a.saha@postgrad.curtin.edu.au
}

\begin{abstract}
This paper reviews the potential use of electric furnace ferronickel slag (FNS) as a fine aggregate and binder in Portland cement and geopolymer concretes. It has been reported that the use of FNS as a fine aggregate can improve the strength and durability properties of concrete. Use of some FNS aggregates containing reactive silica may potentially cause alkalisilica reaction (ASR) in Portland cement concrete. However, the inclusion of supplementary cementitious materials (SCM) such as fly ash and blast furnace slag as partial cement replacement can effectively mitigate the ASR expansion. When finely ground FNS is used with cement, it shows pozzolanic reaction, which is similar to that of other common SCMs such as fly ash. Furthermore, 20\% FNS powder blended geopolymer showed greater strength and durability properties as compared to $100 \%$ fly ash based geopolymers. The utilization of raw FNS in pavement construction is reported as a useful alternative to natural aggregate. Therefore, the use of by-product FNS in construction industry will be a valuable step to help conservation of natural resources and add sustainability to infrastructures development. This paper presents a comprehensive review of the available results on the effects of FNS in concrete as aggregate and binder, and provides some recommendations for future research in this field.
\end{abstract}

Keywords: Ferronickel slag; fine aggregate; supplementary cementitious binder; concrete; geopolymers.

\section{Introduction}

Concrete is the second most consumed material in the world and the demand of concrete is increasing day by day. As a result, about 7.5 billion cubic meters of concrete is produced every year for construction purposes (USGS, 2016). Concrete usage has an annual growth rate of 6\% (Ghods et al., 2017). Generally, a significant part of concrete's volume is occupied by fine aggregate, which plays an essential role in the properties of concrete such as workability, strength and durability. River sand has been used extensively as natural fine aggregate due to its beneficial effects and high availability in many parts of the world. However, excessive and unplanned sand dredging from rivers can cause severe disturbance to the aquatic ecosystem and potentially increase the failure risk of hydraulic structures (Preciso et al., 2012; Liu et al., 1991; Padmalal et al., 2008; Davis et al., 2000). As a result, uses of various alternatives to river sand are explored and used in many parts of the world. Some possible alternative fine aggregates are manufactured sand (M Sand), offshore sand, slag sand, bottom ash, copper slag sand and quarry dust (Masterbuilder, 2014).

Similarly, the use of various industrial by-products as a supplementary cementing material (SCM) has attracted keen interest in the construction industry. Among different SCMs, fly ash, blast furnace slag and steel slag are the most popular and have been studied extensively 
during the last few decades. The application of fly ash and blast furnace slag as SCM can improve the durability properties of concrete significantly by pozzolanic reaction (Achal et al., 2011; Berndt et al., 2009; Lee et al., 2006; Wang et al., 2008a; Wang et al., 2008b; Yeau et al., 2005). However, the binder occupies only a small volume fraction of concrete which is about $12-16 \%$. Besides, grinding of these by-products is energy intensive. Therefore, researchers have been trying to use industrial by-products as aggregate as this needs little or no processing of the raw by-product. It has been reported that the utilization of coal bottom ash, coal fly ash, steel slag, blast furnace slag and plastic wastes as a partial replacement of sand in concrete exhibits satisfactory strength and durability performance. In addition, the application of high density industrial slag as an aggregate improves the strength properties of concrete (Aggarwal et al., 2007; Andrade et al., 2009; Pofale et al., 2010; Yüksel et al., 2007; Ismail et al., 2008). Higher percentages (50\%) of sand replacement by steel slag also improved the strength properties of concrete (Qasrawi et al., 2009). Furthermore, production of self-healing concrete using carbonated steel slag aggregate has been reported in literature (Pang et al., 2016). Steel slag aggregate is not only applicable in concrete production but also can be utilized in road construction, wastewater or gas treatment and as a fertiliser in agriculture production (Yi et al., 2012). On the other hand, the application of bottom ash as a partial replacement of sand reduces the strength properties of concrete due to the low density of the bottom ash than sand; however, it improves the fresh properties and the durability properties including permeability, wettingdrying cycles and freezing-thawing resistance of concrete (Aggarwal et al., 2007; Andrade et al., 2009; Yüksel et al., 2007). Similarly, the inclusion of recycled plastic as fine aggregate reduces the strength of concrete (Ismail et al., 2008). However, the application of fly ash as a partial replacement of sand improves the strength properties of concrete (Pofale et al., 2010).

Recent studies show that, there is a potential to utilize electric furnace ferronickel slags (FNS) as construction materials. FNS is produced as a by-product in nickel smelters. Nickel is produced by smelting of nickel ores in different countries. The nickel ore is smelted in an electric arc furnace at temperatures of about 1500 to $1600{ }^{\circ} \mathrm{C}$ and the by-product molten slag is cooled by water or air (Choi \& Choi, 2015). There are two main types of ores that are commonly used for extraction nickel, one is sulphide ore and the other is garnierite ores. The garnierite ores are mostly used for world nickel production (Dalvi et al., 2004). Garnierite ores generally contain very low percentages of Nickle such as $1 \%$ to $2 \%$. As a result, a significant quantity of slag is generated during the production of nickel (Coey et al., 1999; Saha \& Sarker 2017a; Saha \& Sarker 2017b). It is estimated that approximately 12 to 14 tonnes of nickel slag is produced in the production of one tonne nickel alloy (Saha \& Sarker, 2016). The physical properties of FNS are suitable to use as an alternative to sand in concrete. It has low water absorption and high density and hardness (JSCE, 2016; Sakoi et al., 2013). Due to the presence of a significant amount of amorphous silica, finely ground FNS has shown reactivity when used with Portland cement or with an alkali in geopolymers (Maragkos et al., 2009). FNS aggregate has been successfully used in various construction works where high-density concrete is the primary requirement such as wave-dissipating blocks, cable anchors, rockfill dams and gravity retaining walls (Choi \& Choi, 2015). Therefore, this paper reviews the current state of using FNS as a sustainable construction material.

\section{Properties of FNS}

FNS can be classified into two different classes depending on the cooling method of the molten slag, known as air-cooled slag and water-cooled slag. The air-cooled slag is slowly cooled by the air in an open pit whereas water cooled slag is rapidly cooled by using water as shown in Fig. 1 (Choi \& Choi, 2015). As seen from Fig. 1, air-cooled nickel slag is light grey in colour and brittle in nature. As a result, it can be crushed very easily (Sato et al., 2011). On 
the other hand, water-cooled FNS is dark in colour, spherical in size with hollow structure and slippery in nature (JMIA, 1991).

(a)
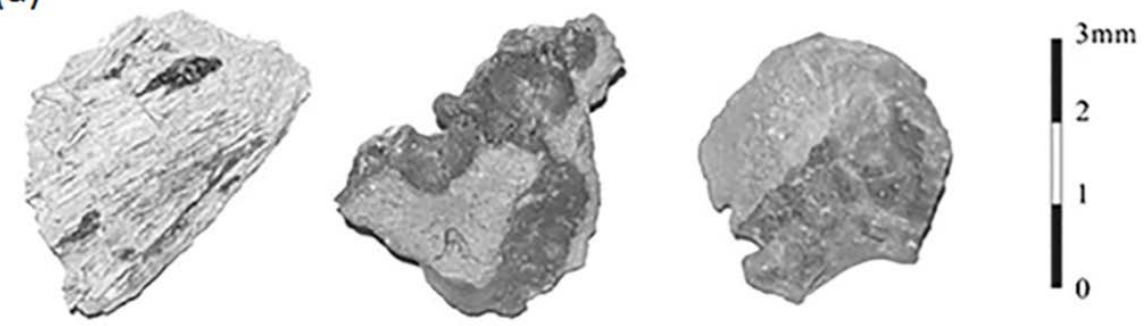

(b)
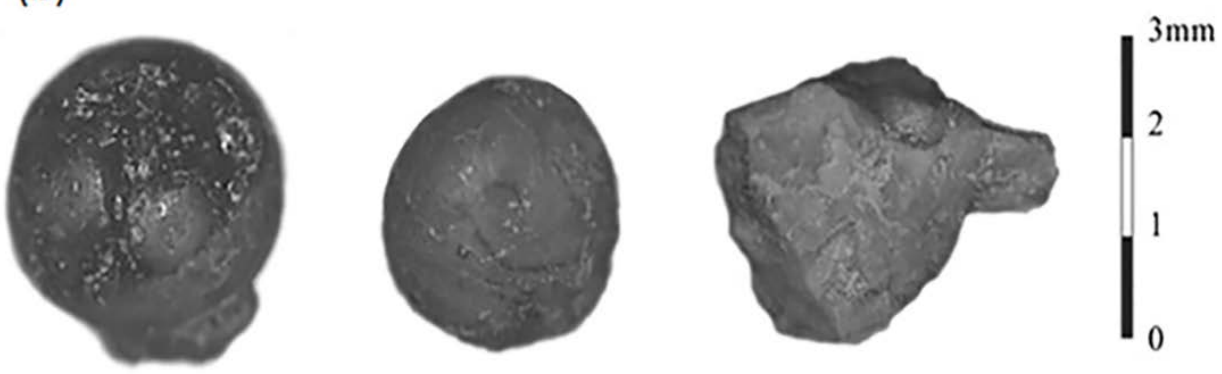

Fig. 1. FNS (a) air-cooled and (b) water-cooled [Choi \& Choi, 2015].

Table 1 Chemical compositions of nickel slag (mass \%).

\begin{tabular}{|c|c|c|c|c|c|c|c|c|c|}
\hline Material & $\begin{array}{c}\text { FNS-A } \\
\text { [Sato et } \\
\text { al., } \\
2011]\end{array}$ & $\begin{array}{l}\text { FNS-W } \\
\text { [Sato et } \\
\text { al., } \\
\text { 2011] }\end{array}$ & $\begin{array}{c}\text { FNS-W } \\
\text { [Komnit } \\
\text { sas et } \\
\text { al., } \\
2007 ; \\
2009 ; \\
2013]\end{array}$ & $\begin{array}{c}\text { FNS-W } \\
\text { [Marag } \\
\text { kos et } \\
\text { al., } \\
\text { 2009] }\end{array}$ & $\begin{array}{l}\text { FNS-W } \\
\text { [Lemon } \\
\text { is et al., } \\
2015]\end{array}$ & $\begin{array}{c}\text { FNS-A } \\
\text { [Choi \& } \\
\text { Choi, } \\
\text { 2015] }\end{array}$ & $\begin{array}{c}\text { FNS-W } \\
\text { [Choi \& } \\
\text { Choi, } \\
\text { 2015] }\end{array}$ & $\begin{array}{c}\text { FNS-W } \\
\text { [Saha \& } \\
\text { Sarker, } \\
\text { 2016;20 } \\
\text { 17a, } \\
\text { 2017b] }\end{array}$ & $\begin{array}{c}\text { FNS } \\
\text { [Fidanc } \\
\text { evska et } \\
\text { al., } \\
\text { 2003] }\end{array}$ \\
\hline $\mathrm{SiO}_{2}$ & 55.6 & 52.7 & 32.74 & 40.29 & 41.18 & 62.80 & 58.1 & 53.29 & 19.8 \\
\hline $\mathrm{Al}_{2} \mathrm{O}_{3}$ & - & - & 8.32 & 10.11 & 5.98 & 1.95 & 2.29 & 2.67 & 12.25 \\
\hline $\mathrm{Fe}_{2} \mathrm{O}_{3}$ & 7.57 & 6.70 & 43.83 & 37.69 & 40.02 & 7.13 & 11.10 & 11.9 & 17.62 \\
\hline $\mathrm{MgO}$ & 27.8 & 34.0 & 2.76 & 5.43 & 7.79 & 24.70 & 26.50 & 31.6 & 9.66 \\
\hline $\mathrm{SO}_{3}$ & 0.06 & 0.04 & 0.18 & - & 0.64 & 0.03 & 0.04 & - & 0.87 \\
\hline $\mathrm{CaO}$ & 5.18 & 2.30 & 3.73 & 3.65 & 4.12 & 2.07 & 0.29 & 0.42 & 4.48 \\
\hline $\mathrm{Na}_{2} \mathrm{O}$ & - & - & - & - & 0.09 & 0.13 & 0.09 & 0.11 & 0.33 \\
\hline $\mathrm{K}_{2} \mathrm{O}$ & - & - & - & - & 0.37 & 0.02 & 0.06 & - & 0.04 \\
\hline $\mathrm{Cr}_{2} \mathrm{O}_{3}$ & - & - & 3.07 & 2.58 & 2.75 & - & - & 1.08 & 2.48 \\
\hline $\mathrm{NiO}$ & - & - & 0.1 & 0.09 & 0.13 & - & - & 0.1 & 0.30 \\
\hline $\mathrm{Co}_{3} \mathrm{O}_{4}$ & - & - & 0.02 & - & 0.02 & - & - & 0.01 & 0.14 \\
\hline $\mathrm{LOI}^{\mathrm{a}}$ & - & - & - & - & - & 0.94 & 1.24 & 0.83 & - \\
\hline $\begin{array}{l}\text { Type of } \\
\text { ores }\end{array}$ & - & - & laterites & laterites & laterites & - & - & garnierit & \\
\hline Source & Japan & Japan & $\begin{array}{l}\text { LARCO } \\
\text {, Greece }\end{array}$ & $\begin{array}{l}\text { LARCO } \\
\text {, Greece }\end{array}$ & $\begin{array}{l}\text { LARCO } \\
\text {, Greece }\end{array}$ & $\begin{array}{l}\text { SNNC, } \\
\text { South } \\
\text { Korea }\end{array}$ & $\begin{array}{l}\text { SNNC, } \\
\text { South } \\
\text { Korea }\end{array}$ & $\begin{array}{l}\text { SLN } \\
\text { New } \\
\text { Caledon } \\
\text { ia }\end{array}$ & - \\
\hline
\end{tabular}

${ }^{\mathrm{a}}$ loss of ignition; FNS-A: air-cooled FNS slag; FNS-W: water cooled FNS slag 
The chemical compositions of FNS obtained from different sources are presented in Table 1. The chemical composition of FNS primarily consists of $\mathrm{SiO}_{2}, \mathrm{MgO}$, and $\mathrm{Fe}_{2} \mathrm{O}_{3}$ (Saha \& Sarker, 2016). This material consists of amorphous silica as well as crystalline minerals such as enstatite, forsterite and dropsied. The chemical compositions of this slag can be different depending on its source, processing and cooling method (Lemonis et al., 2015; Maragkos et al., 2009; Komnitsas et al., 2007). Generally, nickel slag generated from laterite ore contains a high $\mathrm{Fe}_{2} \mathrm{O}_{3}$ and low $\mathrm{MgO}$ whereas, that from garnierite ore contains low $\mathrm{Fe}_{2} \mathrm{O}_{3}$ and high $\mathrm{MgO}$. It is also noticeable that the air-cooled FNS consists of high $\mathrm{SiO}_{2}$, low $\mathrm{MgO}$ and high $\mathrm{CaO}$ compared to the water-cooled FNS (Choi \& Choi, 2015; Sato et al., 2011). The physical properties of FNS are presented in Table 2. It can be seen from the table that generally aircooled FNS shows high density and high water absorption than the water-cooled FNS (Choi \& Choi, 2015; Togawa et al., 1996). In contrast, Sato et al. (2011) reported higher density of air cooled FNS than water-cooled FNS. Therefore, properties of FNS from a new source have to be determined as its properties may vary depending on the source and the processing method.

Table 2 Physical Properties of FNS aggregate

\begin{tabular}{|c|c|c|c|c|c|c|c|c|c|}
\hline $\begin{array}{l}\text { Physical } \\
\text { properties }\end{array}$ & $\begin{array}{l}\text { FNS- } \\
\text { A } \\
\text { [Choi } \\
\& \\
\text { Choi, } \\
\text { 2015] }\end{array}$ & $\begin{array}{l}\text { FNS- } \\
\text { W } \\
\text { [Choi } \\
\& \\
\text { Choi, } \\
\text { 2015] }\end{array}$ & $\begin{array}{l}\text { FNS-W } \\
\text { [Saha \& } \\
\text { Sarker, } \\
\text { 2017c] }\end{array}$ & $\begin{array}{l}\text { FNS- } \\
\text { A } \\
\text { [Sato } \\
\text { et al., } \\
\text { 2011] }\end{array}$ & $\begin{array}{l}\text { FNS- } \\
\text { W } \\
\text { [Sato } \\
\text { et al., } \\
\text { 2011] }\end{array}$ & $\begin{array}{l}\text { FNS- } \\
\text { W } \\
\text { [Sakoi } \\
\text { et al., } \\
\text { 2013] }\end{array}$ & $\begin{array}{l}\text { FNS-W } \\
\text { [Shoya } \\
\text { et al., } \\
\text { 1999] }\end{array}$ & $\begin{array}{l}\text { FNS-A } \\
\text { [Togawa } \\
\text { et al., } \\
\text { 1996] }\end{array}$ & $\begin{array}{l}\text { FNS-W } \\
\text { [Togawa } \\
\text { et al., } \\
1996]\end{array}$ \\
\hline $\begin{array}{l}\text { Specific } \\
\text { gravity } \\
\left(\mathrm{g} / \mathrm{cm}^{3}\right)\end{array}$ & 3.11 & 2.81 & 2.85 & 2.93 & 3.08 & 2.84 & 2.97 & 3.02 & 2.84 \\
\hline $\begin{array}{l}\text { Water } \\
\text { absorption } \\
\text { (\%) }\end{array}$ & 1.64 & 0.71 & 0.42 & 1.87 & 0.13 & 1.98 & 1.2 & 2.20 & 0.73 \\
\hline
\end{tabular}

\section{Performance of FNS as aggregate in concrete}

\subsection{Fresh properties}

\subsubsection{Workability}

Workability is defined as the ease of transportation, placement, compaction and finishing of the concrete mixture. Slump test is the most recognized test to measure the workability of concrete. Workability of concrete primarily depends on water-cement ratio, binder compositions, and aggregates. For example, the concrete mixtures with a constant watercement ratio, the slump variation depends on the aggregate properties such as gradation, particle size, particle density and angularity. A well-graded aggregate exhibits higher workability than a poorly graded aggregate. Besides, larger particles require less water to saturate the surface. Hence, the workability increases with the increase of aggregate particle size for the same water content. Moreover, workability of concrete reduces with the increment of the angularity and the interlocking friction of aggregate (Santamarina, 2008; Hu \& Wang, 2005). The variation of flow value of concrete using FNS aggregate is shown in Fig. 2. Saha and Sarker (2017c, 2017d) determined workability of cement mortar containing FNS fine aggregate using the flow test as per AS 1012.3.1 (2014). It was found that flow of mortar gradually increased up to 50\% replacement of sand by FNS; however, flow then reduced for 
the use of $100 \%$ FNS as fine aggregate. The authors explained that high angularity and large size of FNS aggregate caused internal friction, which reduced the flow of mortar for FNS content of more than 50\%. In contrast, Shoya et al. (1999) found that the workability of concrete reduced marginally with the increase of FNS. The authors conducted both slump flow test and V-funnel flow test to determine the workability of concrete and noticed similar results. The authors described that, due to the poor gradation as well as high angularity of FNS aggregate, it showed higher internal friction between the particles. As a result, it reduced workability of concrete. Moreover, a technical report by Japan Mining Industry Association (JMIA, 1991) indicated that the slump value of FNS aggregate mixed concrete is identical when compared with the conventional aggregate concrete.

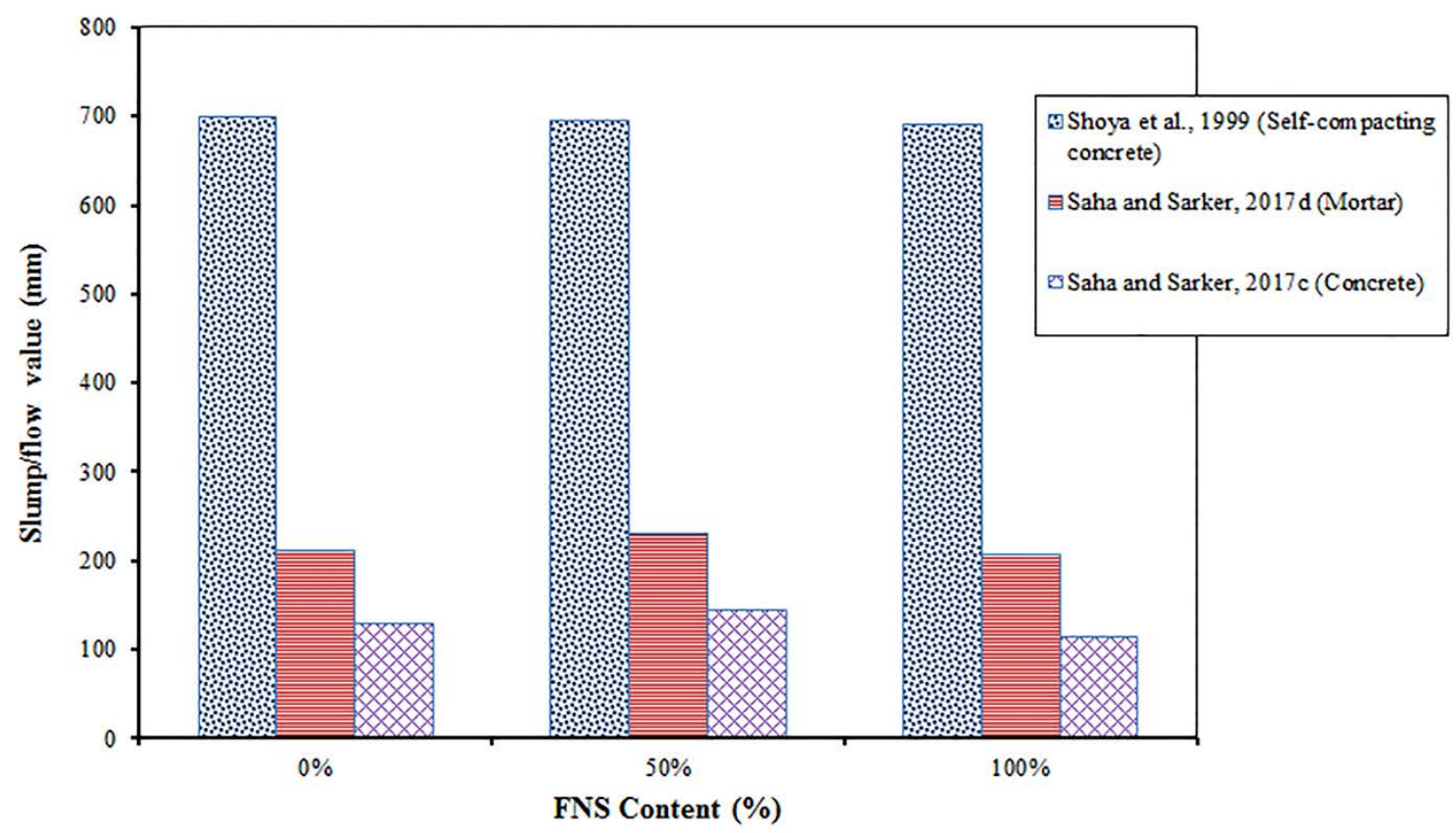

Fig. 2. Workability of FNS concrete/mortar.

\subsubsection{Bleeding}

The accumulation of water on the surface of concrete after compaction and finishing is known as bleeding. Segregation of aggregates is the primary reason behind bleeding of freshly mixed concrete. Usually, high density aggregates exhibit higher bleeding. On the other hand, water has the lowest density among all materials in a concrete mix. As a result, water can easily get separated from the other constituents of a concrete mixture. This phenomenon also depends on other factors such as poor mixing of concrete, excess workability and excessive vibration. FNS aggregate has a higher density than natural sand. Therefore, bleeding of concrete using FNS aggregate is of particular interest. The bleeding properties of concrete using FNS aggregate are shown in Fig. 3. According to the bleeding tests of Shoya et al. (1999) as per JIS A 1123 (1997), FNS aggregate concrete showed identical bleeding as compared to conventional aggregate concrete, and the magnitude of bleeding was below $0.003\left(\mathrm{~cm}^{3} / \mathrm{cm}^{2}\right)$. However, Sato et al. (2011) reported that bleeding of FNS aggregate concrete increased with the increase of FNS content in the mixture. The authors suggested that this increase of bleeding was due to the higher unit weight of FNS aggregate than sand. Thus, consolidation of aggregate particles in a freshly mixed concrete led to increased bleeding. In their study, the amount of bleeding for conventional concrete and $100 \%$ FNS concrete were 0.28 and $0.33\left(\mathrm{~cm}^{3} / \mathrm{cm}^{2}\right)$, 
respectively. Furthermore, Togawa et al. (1996) used furnace slag, silica fume and limestone powder as a SCM in FNS concrete to reduce bleeding.

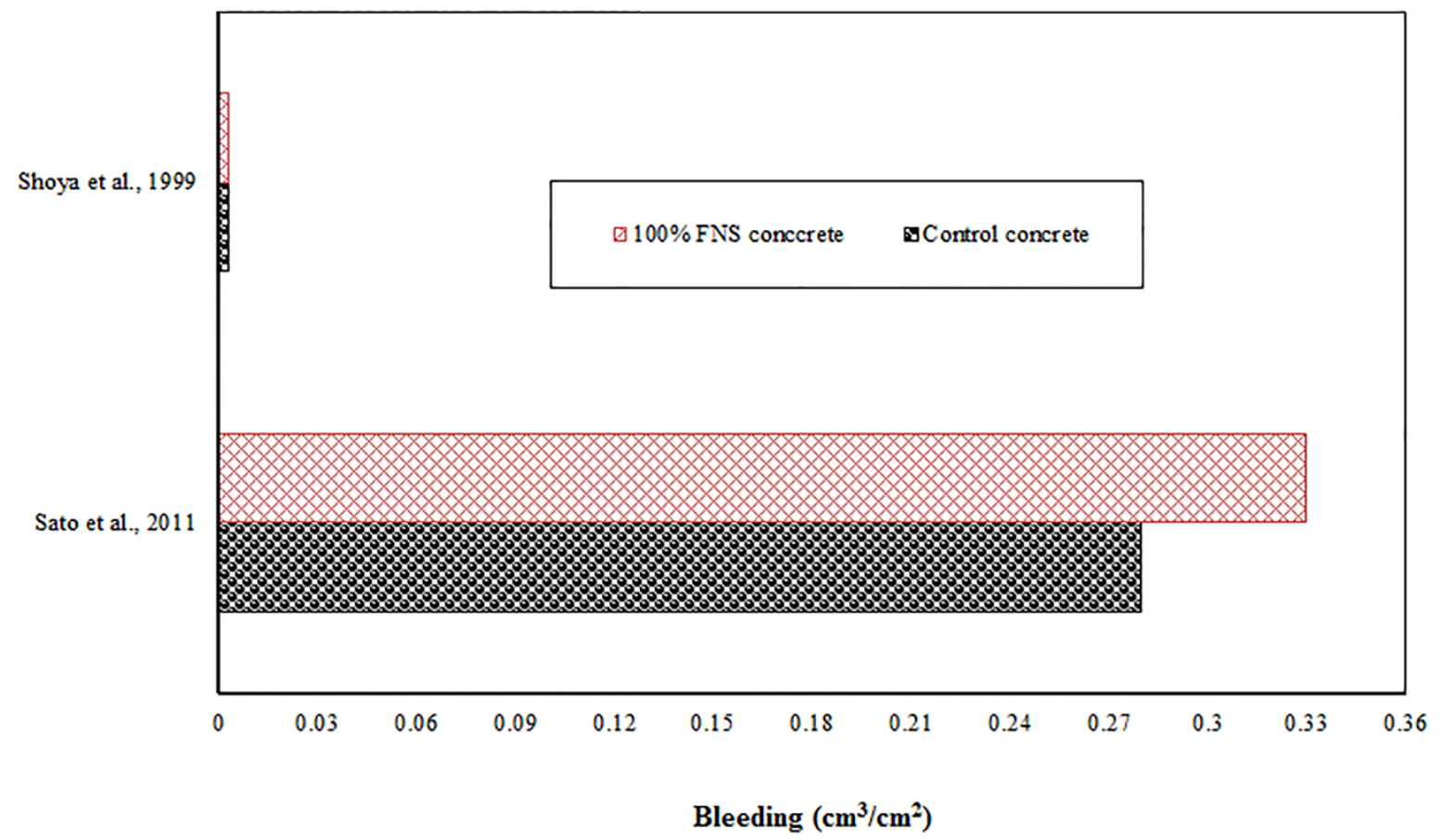

Fig. 3. Bleeding of FNS concrete.

\subsection{Hardened properties}

\subsubsection{Compressive strength}

Compressive strength is the most commonly used hardened properties of concrete. Although aggregate has a significant role on the strength properties of concrete, it depends primarily on binder composition and water-cement ratio. The compressive strength test results of FNS aggregate concrete collected from various published works are presented in Fig. 4. Togawa et al. (1996) found that compressive strength is slightly increased for up to $50 \%$ replacement of sand by FNS; however, there is a reduction in compressive strength at $100 \%$ replacement level. After that, Shoya et al. (1999) showed a similar trend of strength of concrete using FNS aggregate. It can be seen that the compressive strength for control, 50\% FNS, and 100\% FNS concretes were 41.2, 45.7 and $41.7 \mathrm{MPa}$, respectively. The FNS aggregates used in their study had a higher unit weight, fineness modulus and hardness compared to natural sand. As a result, it improved the particle packing when used in concrete. 


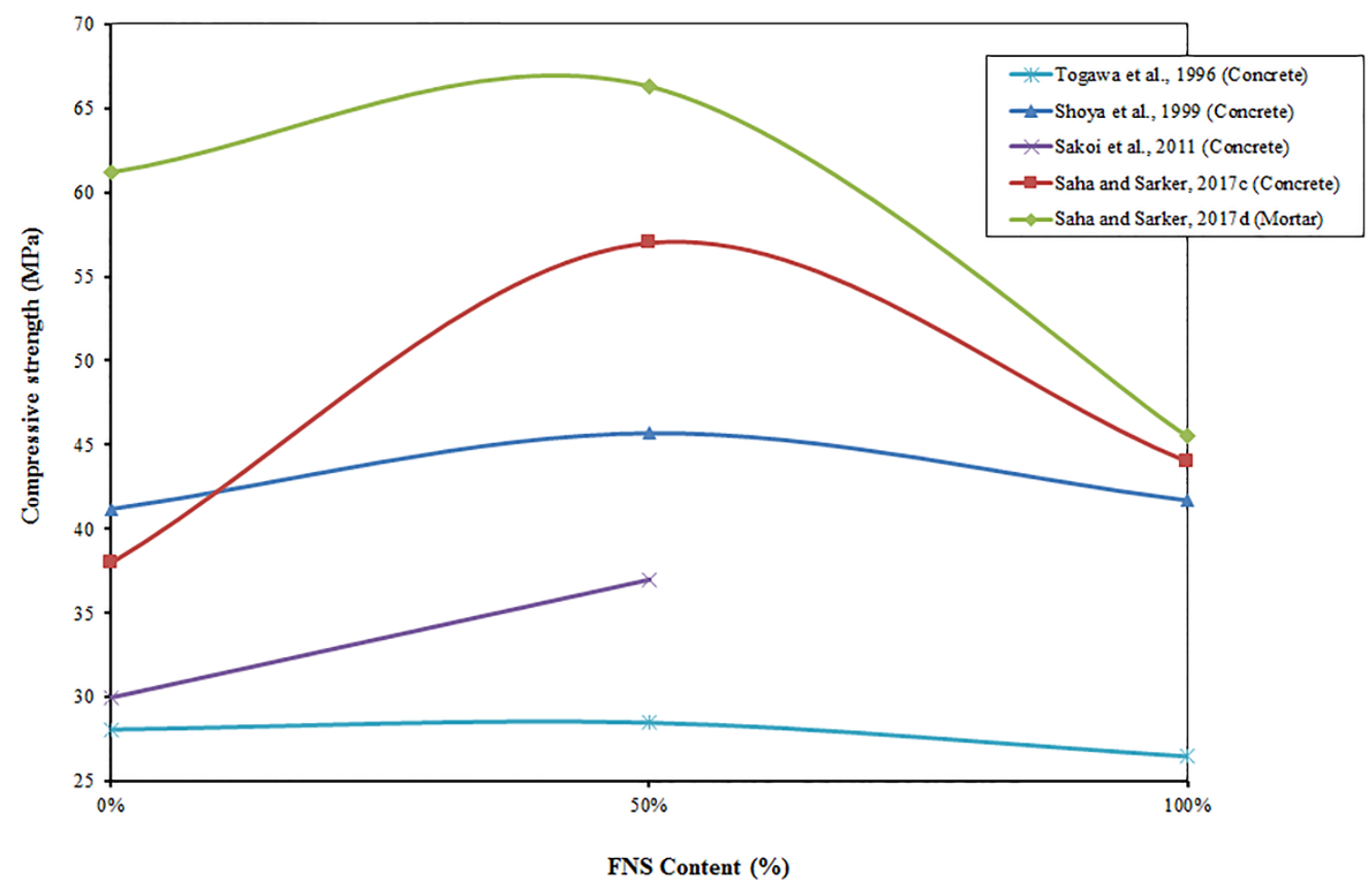

Fig. 4. Compressive strength of FNS concrete.

Therefore, 50\% replacement of sand by FNS aggregates showed better strength performance in concrete, whereas 100\% FNS aggregate reduced the compressive strength of concrete due to the poor gradation of slag aggregates. In addition, full replacement of sand by FNS increased the voids ratio due to high fineness modulus of the FNS aggregates. Similarly, Sakoi et al. (2013) reported that 50\% FNS aggregate showed higher compressive than the normal concrete. Recently, Saha and Sarker (2017c, 2017d) tested both concrete and mortar according to AS 1012.9 (2014) and ASTM C109 (2016), and observed similar phenomena. The FNS used in these studies had higher density and larger particle size compared to sand. Therefore, the compressive strength of concrete increased as a partial replacement of sand by FNS. Higher density and better aggregate gradation of FNS aggregates lead to the increase of compressive strength. On the other hand, full replacement of sand by FNS exhibited lower compressive strength than the control concrete due to the larger size and angularity of the FNS which increased the internal voids.

\subsubsection{Modulus of elasticity}

The modulus of elasticity is a significant property of concrete. This value represents the stiffness and rigidity of concrete material. Modulus of elasticity of concrete is often expressed as a function of its compressive strength. However, modulus of elasticity also depends on the aggregate properties. The modulus of elasticity test results from previous research works are presented in Fig. 5. Sakoi et al. (2013) and Shoya et al. (1999) pointed out that modulus of elasticity of concrete increased with the increase of FNS aggregate content. It can be seen that modulus of elasticity increased from 28 to $32 \mathrm{GPa}$ up to 50\% replacement of sand by FNS (Sakoi et al., 2013). In a similar study, Saha and Sarker (2017c) reported that modulus of elasticity increased with the partial replacement of sand by FNS; however, it then decreased at the full replacement of sand by FNS. Therefore, the higher modulus of elasticity of concrete is 
mainly attributed to the presence of the high density FNS aggregates, which improves the density of concrete by increasing the stiffness and rigidity of concrete samples.

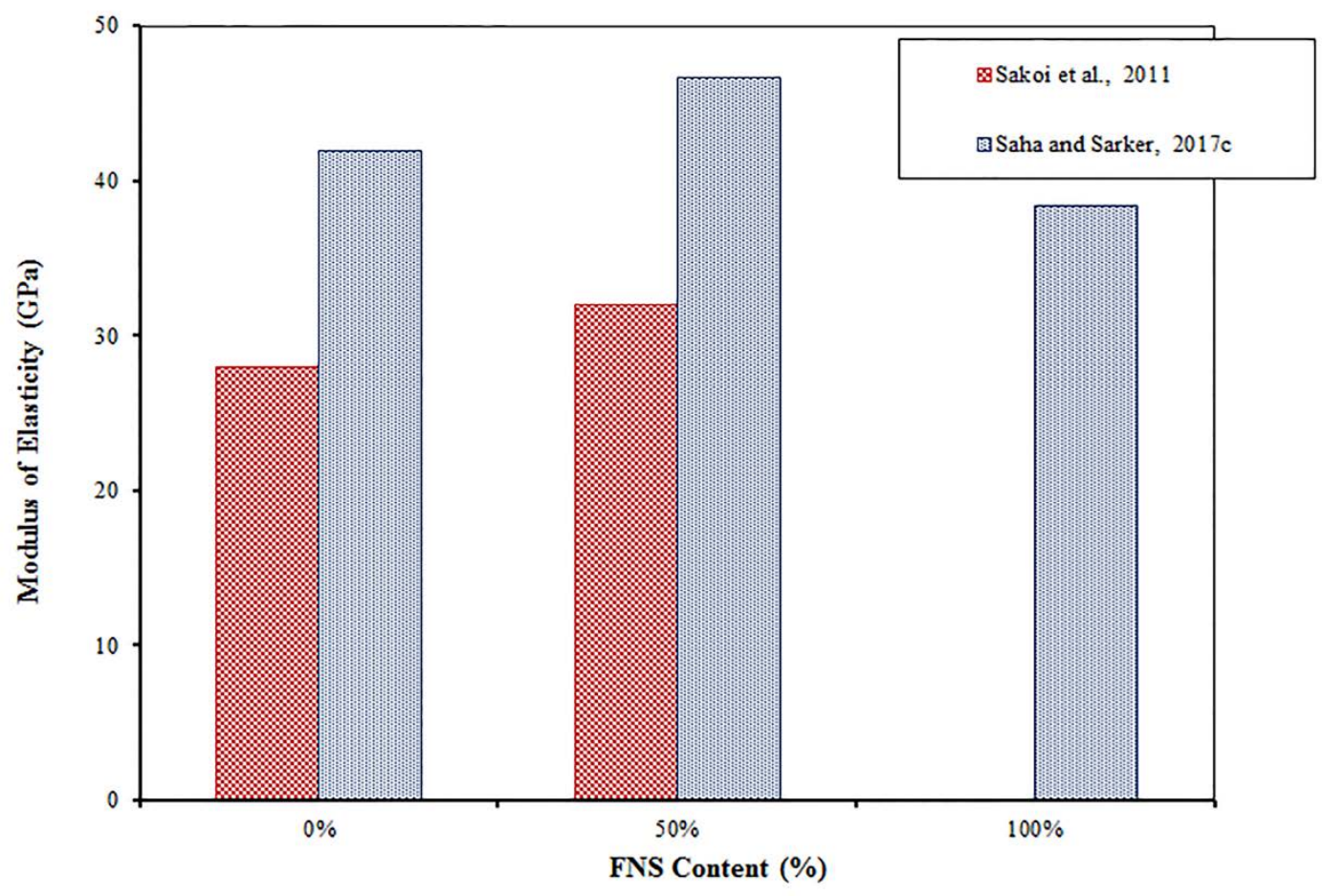

Fig. 5. Modulus of elasticity of FNS concrete.

\subsubsection{Flexural and Tensile strengths}

Generally, concrete is weak in tension. Therefore, the reinforcement came into practice to improve the tensile strength capacity of concrete. Usually, Steel bars in concrete structures carry the majority of the tensile stress. Furthermore, concrete sections without reinforcement can withstand a small amount of tensile stress due to lateral forces and internal stress. This property depends on the compressive strength of concrete as well as the properties of aggregates. Higher angularity and roughness characteristics of aggregate have a positive effect on tensile strength of concrete due to improved friction and interlocking between the binder matrix and aggregate surface (Molugaram et al., 2014; Wu et al., 2001). At the beginning, Shoya et al. (1999) reported that tensile strength of FNS aggregate concrete is identical to that of conventional concrete. Recent test results according to AS 1012.10 (2014) in a study by Saha and Sarker (2017c) are shown in Fig.6. It can be seen that, tensile strength of 50\% FNS aggregate concrete was higher than the control concrete. However, 100\% FNS aggregate concrete showed lower tensile strength than the control concrete. The splitting tensile strengths were 4.33, 4.73 and 3.94 MPa for the control, 50\% FNS and 100\% FNS concrete, respectively. 


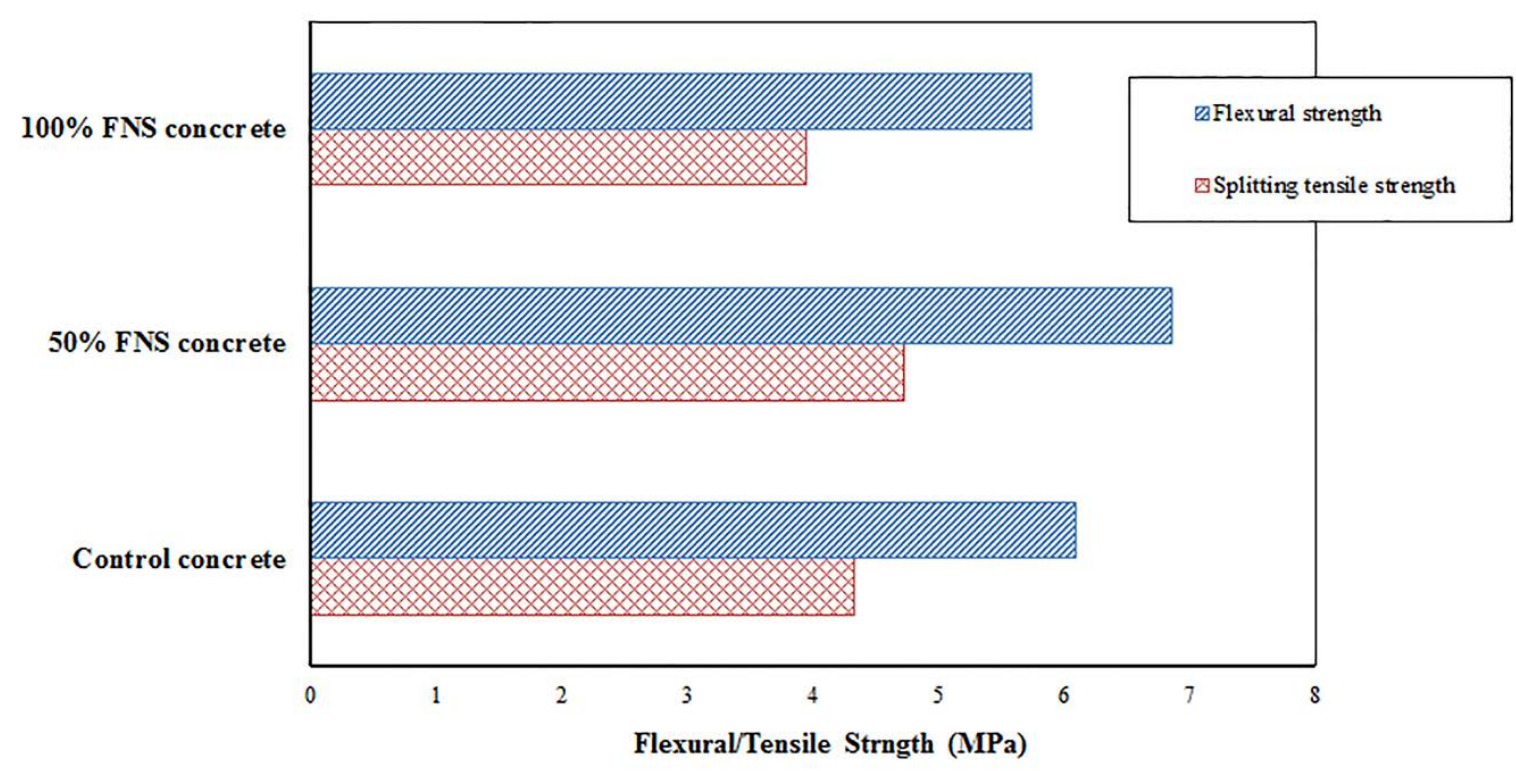

Fig. 6. Flexural and tensile strength of FNS concrete [Saha \& Sarker, 2017c].

FNS concrete also showed similar flexural behaviour, as shown in Fig. 6. Concrete containing 50\% FNS aggregate showed higher flexural strength compared to control concrete; however, strength slightly declined in the 100\% FNS concrete (Saha \& Sarker, 2017c). Therefore, the inclusion of 50\% FNS in fine aggregate improved the tensile and flexural strengths of concrete. However, full replacement sand by FNS resulted in a poor particle size distribution and higher angularity of FNS aggregates that increased the internal voids of the mixture (Saha \& Sarker, 2017c) to result in the decline of strengths.

\subsection{Durability properties}

\subsubsection{Alkali-silica reaction}

Alkali-silica reaction (ASR) is a complex phenomenon in concrete. Although it has been studied extensively during the last few decades, still there is a debate among scientists about its mechanism. Generally, ASR takes place between the reactive silica of aggregates and the alkaline solutions in micro pores of concrete. The primary sources of alkali is the binder matrix. The silica present in aggregates in the form of quartz is chemically inert. However, poorly crystalline silica has an affinity to react with alkali and generate amorphous hydrous silica (Swamy 2002; Ichikawa and Miura 2007). In addition, researchers also investigated the percentage of amorphous silica in reactive aggregates from various sources and the corresponding expansions by accelerated mortar bar test (AMBT) and concrete prism test (CPT) (Grattan-Bellew et al., 2010; Saha and Sarker 2016; Shehata and Thomas 2000; Shafaatian et al., 2013; Moser et al., 2010). The authors noticed that there is an inherent relationship between the expansion of the samples and the percentage of amorphous silica in aggregate. This relationship is that expansion increases with the increase of the percentage of amorphous silica in aggregates. However, the relationship may vary due to the variations in aggregate source, aggregate type and test type. Therefore, the percentage of amorphous silica content in aggregate acts as a governing factor in ASR mechanism and sometimes small proportion of amorphous silica in aggregate can cause expansion of concrete and mortar. 

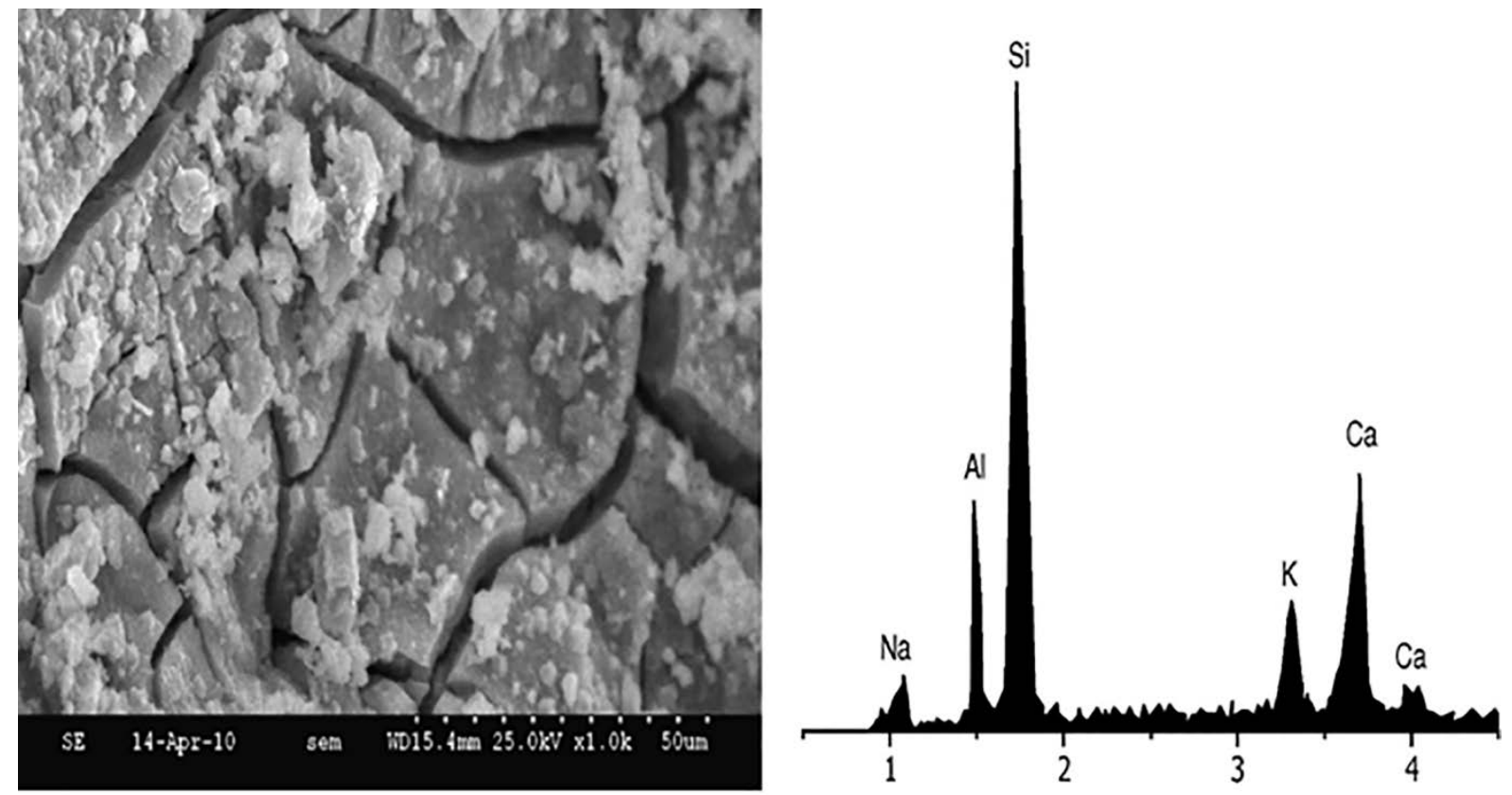

Fig. 7. Microstructure of ASR affected FNS specimen [Choi \& Choi, 2015].

At first, Tomosawa et al. (1997) studied ASR of concrete using FNS aggregates. The authors concluded that the application of low alkali cement and addition of fly ash or ground granulated blast furnace slag are effective measures to suppress the reactivity of FNS aggregates. Then, Choi \& Choi (2015) reported that the water-cooled FNS aggregates showed excessive ASR expansion, whereas air cooled FNS aggregates exhibited small expansion as in control specimens. According to their tests as per ASTM C1260 (2014), the ASR expansion of water-cooled FNS mortar was within a range of 0.6 to $0.8 \%$ after 28 days; however, both the reference mortar and air-cooled FNS aggregate mortar showed approximately 0.05\% expansion. The authors indicated two primary reasons behind the ASR of water-cooled FNS aggregates. Firstly, the rapid cooling of FNS by water leads to formation of microcracks on the surface of FNS particles. As a result, the dissolved silica and water can be transported through the cracks. Secondly, the rapid cooling leads to poorly crystalline and non-crystalline silica in FNS aggregates. The microstructure of ASR affected specimens are given in Figs. $\mathbf{7}$ and $\mathbf{8}$ (Choi \& Choi, 2015; Saha \& Sarker, 2016). It can be seen that the aggregate surface is affected by extensive cracking due to the formation of ASR gel and the chemical composition of this gel confirms the presence of high amount of silica, calcium, alumina and alkali. Recently, Saha and Sarker (2016) pointed out the formation of ettringite in the cracks of ASR affected FNS samples. 

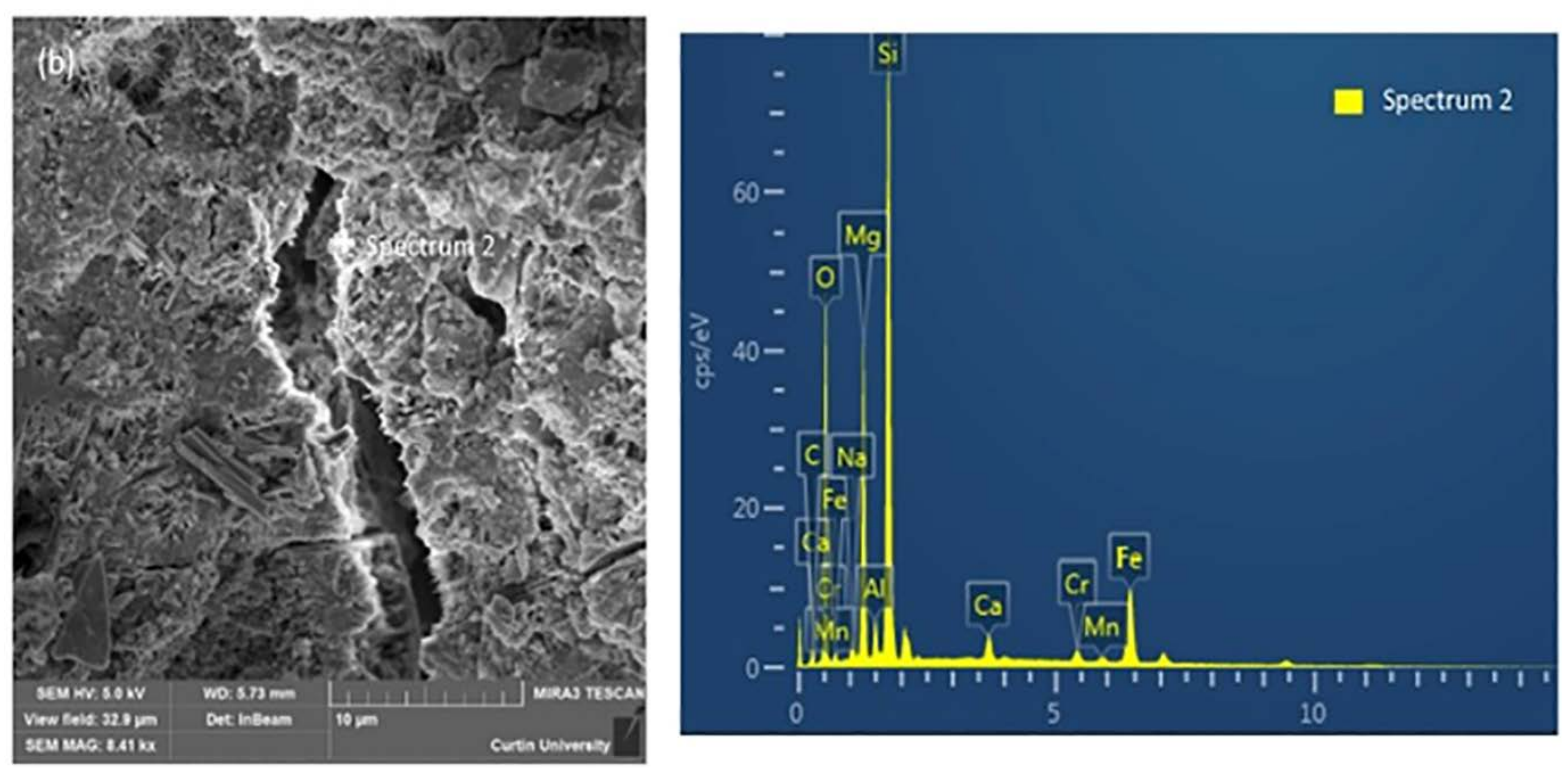

Fig. 8. Microstructure of ASR affected FNS specimen [Saha \& Sarker, 2016].

Initially, the amorphous silica present in the FNS reacts with the alkali, calcium and alumina and generates secondary ettringite, which absorbs moisture. Then, it expands with time and causes significant cracking of the samples (Saha \& Sarker, 2016). It is noticeable that the FNS mortar bars with no fly ash showed expansion of approximately $0.8 \%$; however, with the addition of 5, 10, 20, and 30\% fly ash as SCM, the expansions were 0.70, 0.50, 0.15 and $0.05 \%$, respectively, as shown in Fig. 9 (Choi \& Choi, 2015). Furthermore, 30\% replacement of cement by fly ash resulted an identical expansion to the reference mortar bar. Besides, ground granulated blast furnace slag also can reduce the expansion due to ASR, but a large volume of replacement is required. It has been reported that $60 \%$ replacement of cement by blast furnace slag kept the expansion below the acceptable limit. The expansions of mortar bars for using 15, 30, 45 and 60\% ground granulated blast furnace slag as a SCM were 0.70, 0.55, 0.40 and 0.10\%, respectively (Choi \& Choi, 2015). 


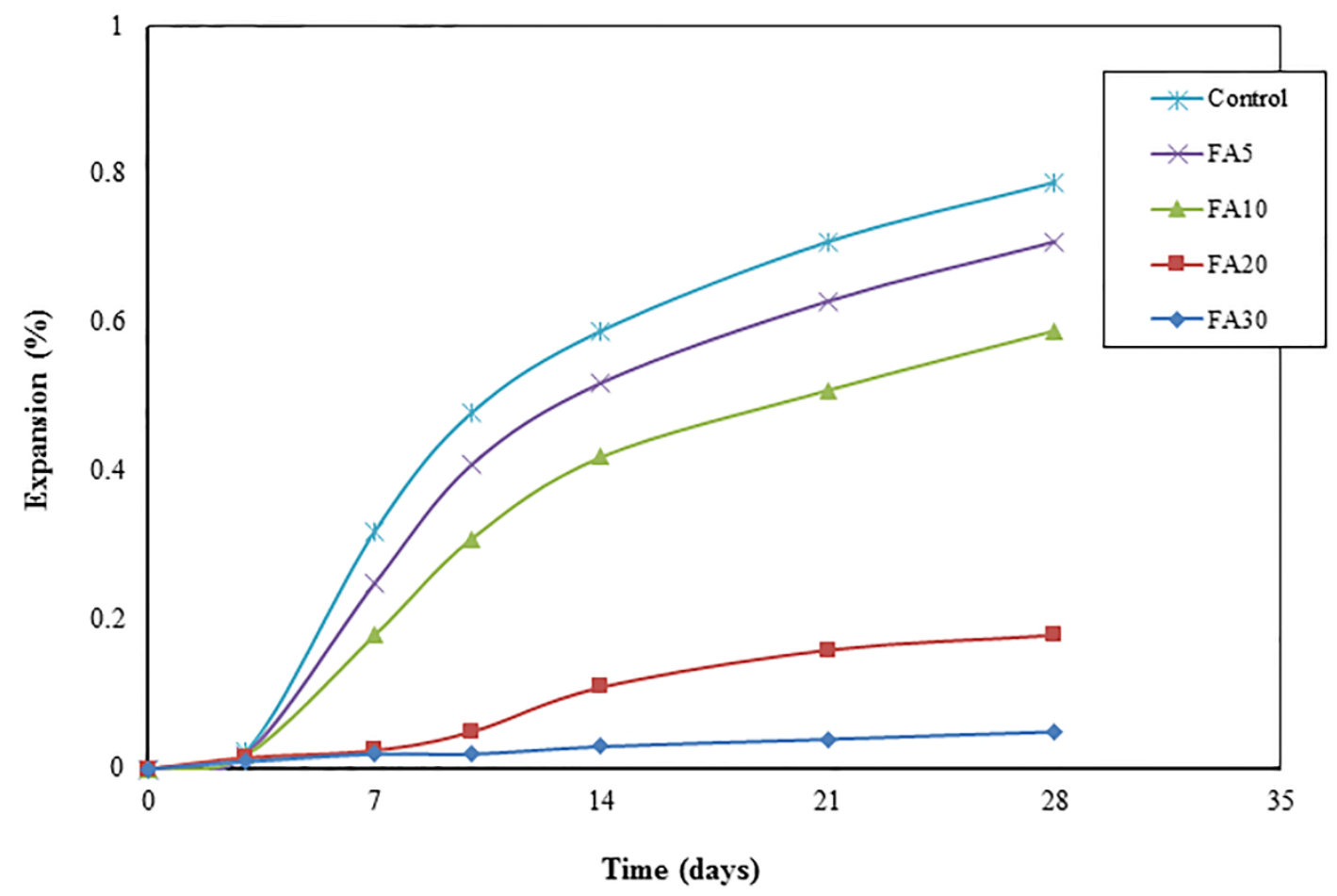

Fig. 9. Influence of class F fly ash in FNS samples as an ASR mitigation technique [Choi \& Choi, 2015].

The mechanism of fly ash to reduce the ASR is mainly dependent on four factors. Firstly, the inclusion of fly ash can reduce the hydroxyl ion in pore solution (Shehata et al., 1999; Shi, 2004). Secondly, it can minimize the pore size and the thickness of the transition zone between cement paste and aggregates (Kuroda et al., 2000; Mehata \& Monteiro, 2006). Thirdly, it can reduce the aggregate dissolution rate (Shafaatian et al., 2013). Lastly, fly ash can reduce the percentage of portlandite from the binder, which acts as a buffer to maintain the pH of pore solution (Hou et al., 2004). Fig. 10. Shows the microstructure of a mortar specimen containing FNS aggregate and fly ash as an SCM after the accelerated mortar bar test (AMBT) (Saha \& Sarker, 2016). It confirms the formation of primary ettringite with a high calcium to silica ratio $(\mathrm{Ca} / \mathrm{Si})$ due to the hydration of cement and the pozzolanic reaction of fly ash that has the properties of low viscosity and swelling pressure (Vayghan et al., 2016). Therefore, the use of fly ash as an SCM is considered an adequate measure to mitigate the potential ASR of FNS fine aggregate. 

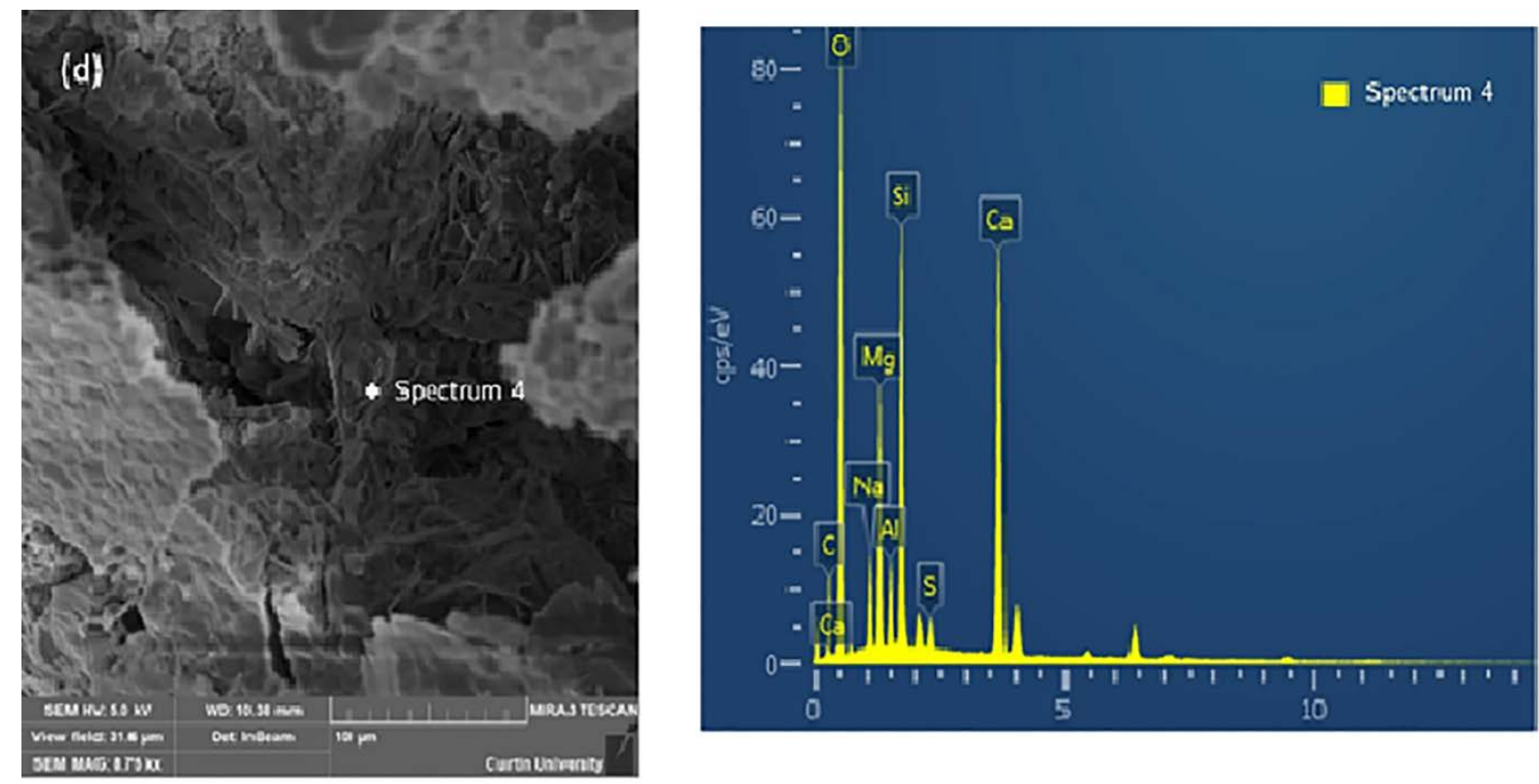

Fig. 10. Microstructure of FNS Samples with 30\% fly ash under AMBT [Saha \& Sarker, 2016].

\subsubsection{Freezing and thawing resistance}

Resistance to freezing and thawing cycles evaluates the soundness of concrete in exposures to adverse weather conditions. Concrete samples are exposed to the repeated cycles of freezing and thawing in this test. Usually, the samples are exposed to $-18{ }^{\circ} \mathrm{C}$ for freezing and $4{ }^{\circ} \mathrm{C}$ for thawing in a cyclic order within 2 to 5 hours. The freezing and thawing resistance test results are found in various published are presented in Table 3.

Table 3 Freeze and thaw resistance of FNS concrete.

\begin{tabular}{|c|c|c|c|}
\hline FNS (\%) & $\begin{array}{c}{ }^{1} \text { RDME (\%) } \\
300 \text { Cycles [Sakoi et al., } \\
2013 \text { ] }\end{array}$ & $\begin{array}{c}\text { RDME (\%) } \\
300 \text { Cycles [Sato et al., } \\
2011]\end{array}$ & $\begin{array}{c}{ }^{2} \mathrm{DF}(\%) \\
300 \text { Cycles } \\
\text { [Shoya et al., } \\
1999]\end{array}$ \\
\hline 0 & 85 & 85 & 71.6 \\
\hline 25 & - & 82 & - \\
\hline 50 & 82 & - & 84.7 \\
\hline 100 & - & 80 & 86.4 \\
\hline
\end{tabular}

${ }^{1}$ Relative Dynamic Modulus of Elasticity; ${ }^{2}$ Durability Factor

It can be seen that two different kinds of assessments are adopted in determination of the resistance against freeze-thaw exposures, namely dynamic modulus of elasticity and durability factor. In tests according to JIS A 1148 (2010), Sakoi et al. (2013) found that FNS samples showed almost similar relative dynamic modulus of elasticity after freeze and thaw cycles when compared to the control specimens. On the other hand, Sato et al. (2011) reported a decreasing trend of relative dynamic modulus of elasticity for FNS samples. Besides, Togawa et al. (1996) suggested that the use of limestone powder can improve the durability characteristics of FNS concrete. Shoya et al. (1999) reported that durability factor of FNS 
concrete increased as compared to control concrete after the freeze and thaw cycles tested as per ASTM C 666 (1992). From Table 3, it can be seen that the durability factor was slightly over $70 \%$ for the control specimens, whereas the durability factors of specimens containing $50 \%$ and $100 \%$ FNS were $85 \%$ and $87 \%$, respectively. This increase of durability factor was attributed to the higher density and lower fineness modulus of FNS aggregates than natural sand.

\subsubsection{Drying shrinkage}

The loss of capillary water from the hardened concrete mix leads to contraction of concrete which is known as drying shrinkage. High drying shrinkage can cause internal cracks and warping as well as external deflection in concrete. Generally, drying shrinkage of concrete depends on cement paste volume, water-cement ratio and water absorption of aggregates. The drying shrinkage test results of FNS aggregate concrete are presented in Table 4.

Table 4. Drying shrinkage of FNS concrete.

\begin{tabular}{|c|c|c|}
\hline \multirow{2}{*}{ FNS (\%) } & \multicolumn{2}{|c|}{ Drying shrinkage $\left(\times 10^{-5}\right.$ strain $)$} \\
\hline & [Sakoi et al., 2013] & [Shoya et al., 1999] \\
\hline 0 & 35 & 51 \\
\hline 50 & 40 & 45 \\
\hline 100 & - & 42 \\
\hline
\end{tabular}

Shoya et al. (1999) showed that the use of FNS as aggregate in concrete reduced drying shrinkage slightly as compared to the control concrete. In their tests the drying shrinkage for control, 50\% FNS and 100\% FNS concrete were 510, 450 and 420 micro strains, respectively. The water content of these specimens were 165,160 and $155 \mathrm{~kg} / \mathrm{m}^{3}$, respectively. Therefore, FNS aggregate concrete specimens with the lower water-cement ratio resulted in lower drying shrinkage, as expected. However, Sakoi et al. (2013) found that drying shrinkage of FNS concrete was slightly higher than control specimens. High water absorption of FNS aggregates resulted in greater drying shrinkage of these samples since the water cement ratio was kept constant for all the mixes. The drying shrinkage ranged between 350 and 400 micro strains in their study under. Nevertheless, drying shrinkage of the specimens containing FNS aggregate was within the range of values usually observed in concrete using natural sand as fine aggregate.

\subsubsection{Air permeability and carbonation}

The air permeability test evaluates the pores in concrete and it gives an indication of the ease of transportation of fluids into concrete. Besides, carbonation is the reaction between $\mathrm{CO}_{2}$ from the surroundings and $\mathrm{Ca}(\mathrm{OH})_{2}$ of binder matrix that forms $\mathrm{CaCO}_{3}$. Since the carbonation process uses $\mathrm{Ca}(\mathrm{OH})_{2}$, it reduces the $\mathrm{pH}$ of concrete which may increase the risk of reinforcement corrosion. Shoya et al. (1999) determined air permeability and carbonation of FNS aggregate concrete samples using the method proposed by Nagataki and Ujike (1988). The authors used $490 \mathrm{kPa}$ load-bearing pressure and the water replacement method to determine the amount of air penetrated through the concrete. The authors reported that the air permeability of FNS concrete samples were similar to the control concrete. The coefficient of air permeability ranged between $2.51 \times 10^{-5}$ and $2.44 \times 10^{-5} \mathrm{~m} / \mathrm{sec}$. Furthermore, the carbonation 
test of FNS concrete gave identical result to that of the control specimen. The neutralised depth of the concrete samples remained between 6.97 and $5.72 \mathrm{~mm}$ after 91 days (Shoya et al., 1999).

\subsection{Applications in pavement constructions}

Different types of industrial slag have been utilised in pavement construction as base and sub-base aggregates or as a cementitious material in recent decades. Significant research work has been carried out on the use of electric arc furnace slag (EAF) both as coarse aggregate and fine aggregate in pavement constructions (ASA, 2002; Behnood \& Ameri, 2012; Wu et al., 2007; Ziari et al., 2015; Oluwasola et al., 2015; Oluwasola et al., 2015). As a coarse aggregate, this slag exhibits high skid resistance due to high angularity in surface dressing (Pasetto \& Baldo 2006). In addition, the application of EAF as a coarse aggregate provides satisfactory results in asphalt in terms of strength, water sensitivity, stability and deformation (Ameri \& Behnood, 2012). Furthermore, Marshall Stability and flow are significantly higher in asphalt using EAF coarse aggregate (Ahmedzade \& Sengoz, 2009). Besides, the combination of EAF as a coarse aggregate with limestone as a filler provides satisfactory results. Ziari et al. (2015) reported that replacement of fine aggregate by 50\% EAF aggregate in hot mix asphalt showed satisfactory performance by the reduction of air voids and improvement of stiffness. The use of this slag as a fine aggregate improves the mechanical properties such as tensile strength and stability of asphalt (Ameri et al., 2013; Behnood \& Ameri, 2012). Moreover, resilient modulus of asphalt improved significantly by the use of slag aggregate which is almost twice as compared to traditional asphalt (Hainin et al., 2012; Hainin et al., 2013; Hainin et al., 2014). However, asphalt with EAF as a fine aggregate shows poor performance in water submergence test (Bagampadde et al., 1999). This is may be due to the presence of significant amount of impurities in industrial slag. Therefore, Emery (1984) suggested to remove the impurities such as lime, refectory and wood from industrial slags before its use in asphalt mixtures as aggregate. The physical properties of EAF and FNS aggregates are relatively similar as both type of aggregate possess high density, low water absorption and angular shaped particles (Saha \& Sarker, 2017c; Bagampadde et al., 1999; Ziari et al., 2015). Some researchers investigated the suitability of the FNS aggregates as a fine aggregate in hot mix asphalt (HMA) (Emery et al., 1984; Wang et al., 2011; Wang \& Thompson, 2011; Krayushkina et al., 2012).

Emery (1984) initially adopted nickel slag aggregate as a base material in mining road and found that nickel slag exhibited satisfactory performance in adverse traffic operating conditions. Wang et al. (2011) conducted accelerated laboratory testing by asphalt pavement analyser in order to evaluate the durability of asphalt using slag aggregate. Furthermore, the authors carried out petrographic examination to identify reactive silica and autoclave testing for evaluation of free lime and free magnesia of the FNS aggregates. According to the test results, the authors concluded that nickel slag is mineralogically, physically and environmentally stable and can be adopted as coarse aggregate and fine aggregate in HMA. Similarly, Wang and Thompson (2011) suggested that air cooled FNS can be used as a suitable alternative to traditional aggregates in the base course and HMA. In addition, Krayushkina et al. (2012) showed that FNS is a suitable alternative for HMA and can be used as a base course in a highway construction. However, research works carried out with FNS aggregate in pavement construction is very limited. Therefore, more research is necessary to carry out in the area of pavement constructions.

\section{Performance of ground FNS as binder in concrete}

It is well known that production of cement emits a significant amount of $\mathrm{CO}_{2}$ to the atmosphere. Therefore, researchers have been working since the past few decades on various 
industrial by-products such as blast furnace slag, fly ash, steel slag, copper slag, sugarcane bagasse ash, ladle furnace slag and basic oxygen furnace slag as SCM during (Das et al., 2007; Shi \& Qian, 2000; Loh et al., 2013; Shi et al., 2008; Rodriguez et al., 2009; Carvalho et al., 2017). The utilization of blast furnace slag as a SCM in concrete reduces the heat of hydration and improves the long-term strength and durability properties (Das et al., 2007). Similarly, fly ash blended concrete exhibits high durability properties including resistance to alkali silica reaction; sulphate and acid attacks (Saha \& Sarker, 2016; Saha \& Sarker 2017c; Shi \& Qian, 2000). Besides, copper slag, sugarcane bagasse ash, ladle furnace slag, basic oxygen furnace slag can improve the strength and durability of concrete due to the presence of high amorphous silica and low free lime or magnesia (Loh et al., 2013; Shi et al., 2008; Rodriguez et al., 2009; Carvalho et al., 2017). On the other hand, steel slag consists of excessive free lime, which can cause deleterious volume expansion (Shi \& Qian, 2000). Thus, industrial waste containing high amorphous silica and low free $\mathrm{CaO}$ or $\mathrm{MgO}$ can be used as SCM. The chemical properties of FNS, as presented in Table 1, shows that it usually contains high silica. However, FNS from some sources have very high amount of $\mathrm{MgO}$, which is over $20 \%$. Excessive amount of free magnesia can cause volumetric instability of concrete.

Mo et al. (2005) pointed out that the presence of high MgO in binder reduces shrinkagecracking in concrete. This MgO leads to an autogenous expansion in later curing ages, as a result, it can compensate the concrete's contraction due to cold weather and shrinkage (Mo et al., 2005). However, the maximum allowable limit of MgO in a SCM is $15 \%$ as per AS 3582.2 (2016). It generates Bruucite $\left(\mathrm{Mg}(\mathrm{OH})_{2}\right)$ by the hydration of $\mathrm{MgO}$, which is expansive in nature. As a result, it can increase the concrete volume by up to $17 \%$ and also lead to loss of strength. Rahman et al. (2017) studied the soundness and the strength properties of FNS blended concrete. The authors found that the strength properties were slightly lower due to reduction of lime content. On the other hand, the soundness test results including Le-Chatelier, autoclave and extended heat curing were within the allowable limit in FNS samples. In addition, X-ray diffraction (XRD) analysis traced the presence of MgO in the form of forsterite as presented in Fig. 11. The crystalline structure of forsterite is orthorhombic, which is chemically inert and stable (Klein et al., 1998). Therefore, the MgO present in the form of forsterite does not participate in hydration reaction to produce expansive $\mathrm{Mg}(\mathrm{OH})_{2}$ (Maghsoudlou et al., 2016; Kosanović et al., 2005). Therefore, FNS samples did not show any significant expansion in soundness tests (Rahman et al., 2017). 


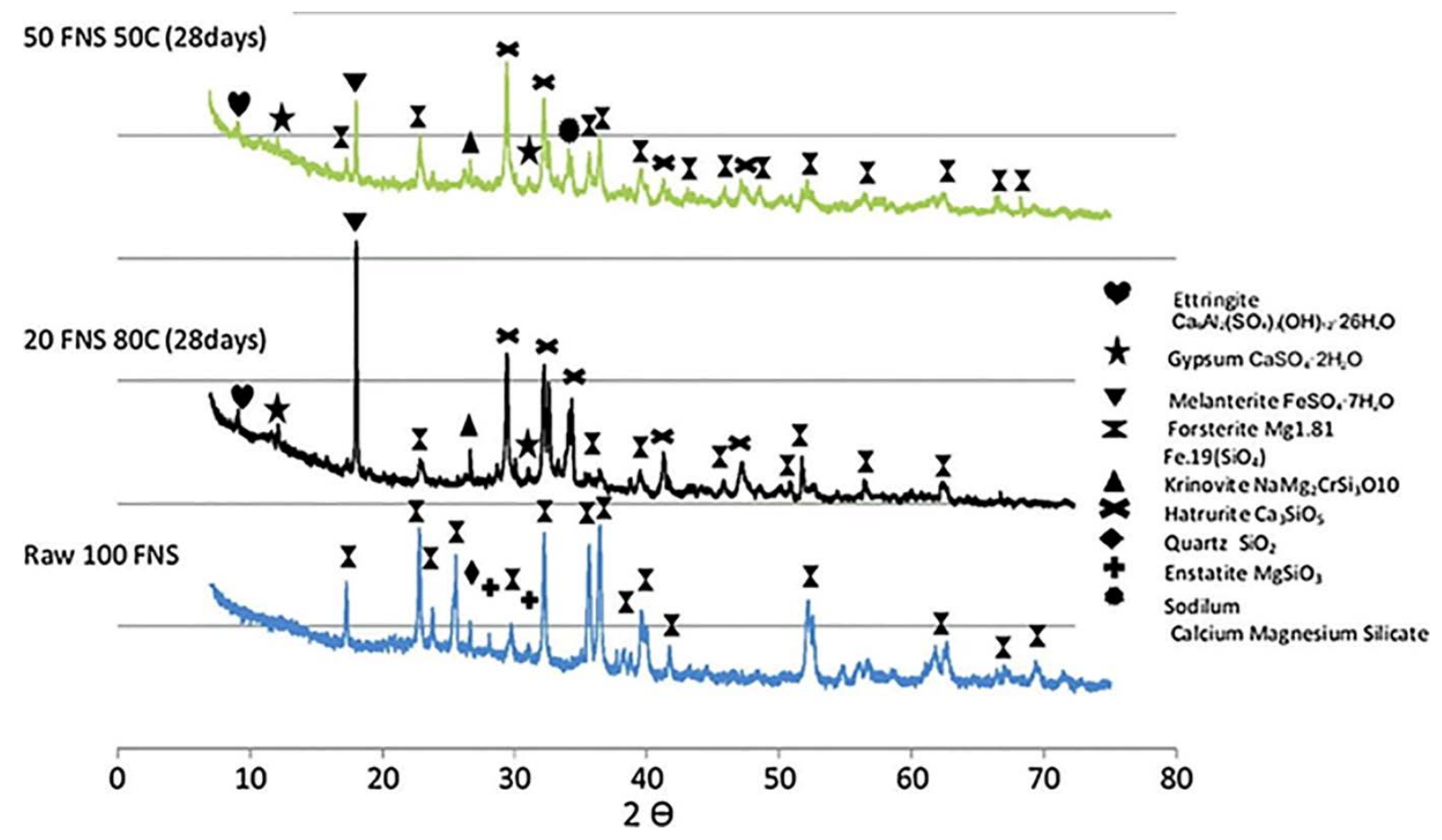

Fig. 11. Phase analysis of raw FNS and FNS blended cement pastes [Rahman et al., 2017].

Furthermore, Lemonis et al. (2015) conducted a hydration study on the FNS blended samples and found that the FNS blended samples exhibited a slower rate of hydration than the control samples. Thus, the compressive strength development was slower in FNS mixed concrete than in the conventional cement concrete. However, the amorphous silica present in FNS reacted at the later ages and formed secondary calcium silicate hydrate (C-S-H) gel and improved the density of microstructure. The study also showed that the use of ground FNS as part of the binder similar water demand as for the control mix. Similarly, Katsiotis et al. (2015) concluded that the presence of FNS slowed down the hydration process and the strength development in FNS blended concrete. In addition, the authors reported an increase of compressive strength at later stages of curing due to the effect pozzolanic reaction of FNS. FNS has not been studied extensively by the scientific community unlike fly ash or blast furnace slag. Therefore, further research is recommended in this area.

\section{Performance of FNS in geopolymer}

Geopolymer is an emerging alternative binder to Portland cement. Significant amount of research has been carried out on the development of geopolymer concrete during the recent time (Hardjito et al., 2005; Hardjito et al., 2004; Geopolymer Institute, 2017; Yang et al., 2014; Zheng et al., 2010; Zhang et al., 2017). Geopolymer is considered as a binder of low carbon footprint since Portland cement is replaced by industrial by-products such as fly ash, metakaolin or slag. In geopolymerisation, an aluminosilicate material such as fly ash, GGBFS or metakaolin is activated by an alkaline solution to generate three-dimensional polymeric chains (Hardjito et al., 2005). It was shown in past works that strength and durability of geopolymer concrete are comparable to those of Portland cement concrete (Hardjito et al., 2004). As a result, geopolymer concrete has been recently used in some industrial applications. One example is the Brisbane West Wellcamp Airport (BWWA) in Australia constructed in 2014 (Geopolymer Institute, 2017). 
It is noticeable from the chemical compositions of FNS that it contains substantial amounts of $\mathrm{SiO}_{2}$ and $\mathrm{Al}_{2} \mathrm{O}_{3}$. Thus, it has the potential to replace fly ash partially or entirely in fly ash based geopolymer concrete. Yang et al. (2014) showed that 20\% FNS was found to be an optimum quantity as a binder in geopolymer concrete that exhibited the highest strength and lowest shrinkage properties. The authors explained that the FNS contained high $\mathrm{SiO}_{2}$ and $\mathrm{MgO}$ with relatively low $\mathrm{Al}_{2} \mathrm{O}_{3}$ as compared to fly ash. Consequently, it increased the $\mathrm{Si} / \mathrm{Al}$ ratio of the geopolymer ingredients and improved compressive strength. The microstructural images of $0 \%$ and 20\% FNS geopolymer concrete are presented in Fig. 12, it can be seen that microstructure of $20 \%$ FNS geopolymer specimens were denser as compared to the specimens without FNS. However, a higher dosage of FNS (40\% and 60\%) led to the reduction of strength due to lower Si/Al ratio $(<2)$ and presence of large pores. In addition, Zheng et al. (2010) suggested an intermediate $\mathrm{Si} / \mathrm{Al}$ ratio for the optimum results. In another study by Yang et al. (2014) pointed out that, MgO present in the FNS experienced an elevated temperature extractive metallurgy, thus became inert. As a result, the issue regarding the volume stability in fly ash in geopolymer concrete was not noticeable due to the addition of FNS as a binder.
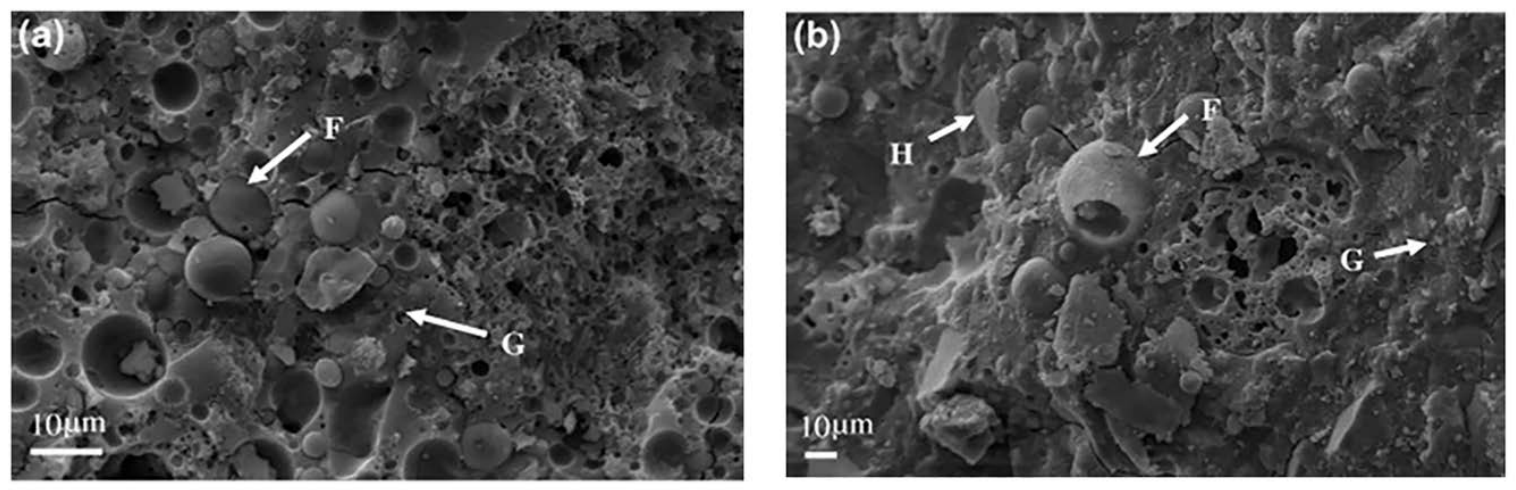

Fig. 12. Microstructure of fly ash geopolymer with (a) $0 \%$ FNS and (b) $20 \%$ FNS. (F-fly ash particles, H-HMNS particles, G-gel phase formed.) [Yang et al., 2014].

In another study, Zhang et al. (2017) reported that the use of $20 \%$ and $40 \%$ FNS in geopolymer improved compressive strength as compared to fly ash based geopolymer. The authors also pointed out that FNS geopolymer has an emission of 0.19-0.23 tonnes of $\mathrm{CO}_{2}$ per tonne of concrete, which is significantly less than the traditional cement concrete. Furthermore, microstructure analysis revealed formation of $\mathrm{Na}-\mathrm{Al}(\mathrm{Mg})-\mathrm{Si}-\mathrm{O}-\mathrm{H}$ gel in the FNS based geopolymers. Therefore, the authors concluded that the MgO present in the FNS was not chemically inert since it took part in the geopolymerisation process. Furthermore, according to Maragkos et al. (2009), the characteristics of FNS geopolymer depends on the solid to liquid ratio $(\mathrm{S} / \mathrm{L})$. The optimum quantity of $\mathrm{S} / \mathrm{L}$ and $\mathrm{NaOH}$ concentration were $5.6 \mathrm{~g} / \mathrm{mL}$ and $7 \mathrm{M}$, respectively in their study. This optimum conditions exhibited a significantly high compressive strength of $118 \mathrm{MPa}$ and very low water absorption of about $0.8 \%$. In addition, Komnitsas et al. (2007) investigated the properties of kaolinite based geopolymer with ground FNS blends. The authors found that heating time and the temperature had a negligible effect on the compressive strength, whereas curing period had a prominent effect on strength development. The reaction phases of geopolymer binders were identified by XRD, the results are shown in Fig. 13 (2007). The presence of various minerals such as trona, sodalite, thermonatrite and maghemite can be seen in the geopolymer binders. These minerals are primarily composed of $\mathrm{Na}, \mathrm{Si}, \mathrm{Al}$ and $\mathrm{O}$. It is noticeable that there was no sign of $\mathrm{MgO}$ in the chemical analysis. Thus $\mathrm{MgO}$ present in FNS acted as inert in the chemical reactions. It can be noted that the geopolymer samples showed excellent resistance to freeze-thaw cycles. However, it displayed 
strength loss in the acidic environment due to the formation of aragonite, akermanite, halite, magnesium calcite and calcite minerals on the surface of the samples. These minerals are formed due to carbonation under acidic environment. Komnitsas et al. (2009) pointed out that the presence of alkali in FNS accelerated the hydration process. The authors confirmed that only $\mathrm{Si}, \mathrm{Al}$ and $\mathrm{O}$ participated in hydration reaction by using Fourier Transform Infrared Spectroscopy (FTIR) analysis. Finally, Komnitsas et al. (2013) also evaluated the effect of $\mathrm{NO}_{3}{ }^{-}$or $\mathrm{SO}_{4}{ }^{-2}$ in the geopolymer mixture. According to the experimental results, the presence of these ions reduced strength development due to the consumption of alkali, thus minimized the formation of a gel. Besides, Sakkas et al. (2014) evaluated the effect of fire exposure on the FNS based geopolymer. The authors found that these geopolymers had a low thermal conductivity and high fire resistance like commercial fire resisting materials. The authors also reported $120 \mathrm{MPa}$ compressive strength, which is in the ultra-high strength concrete category.

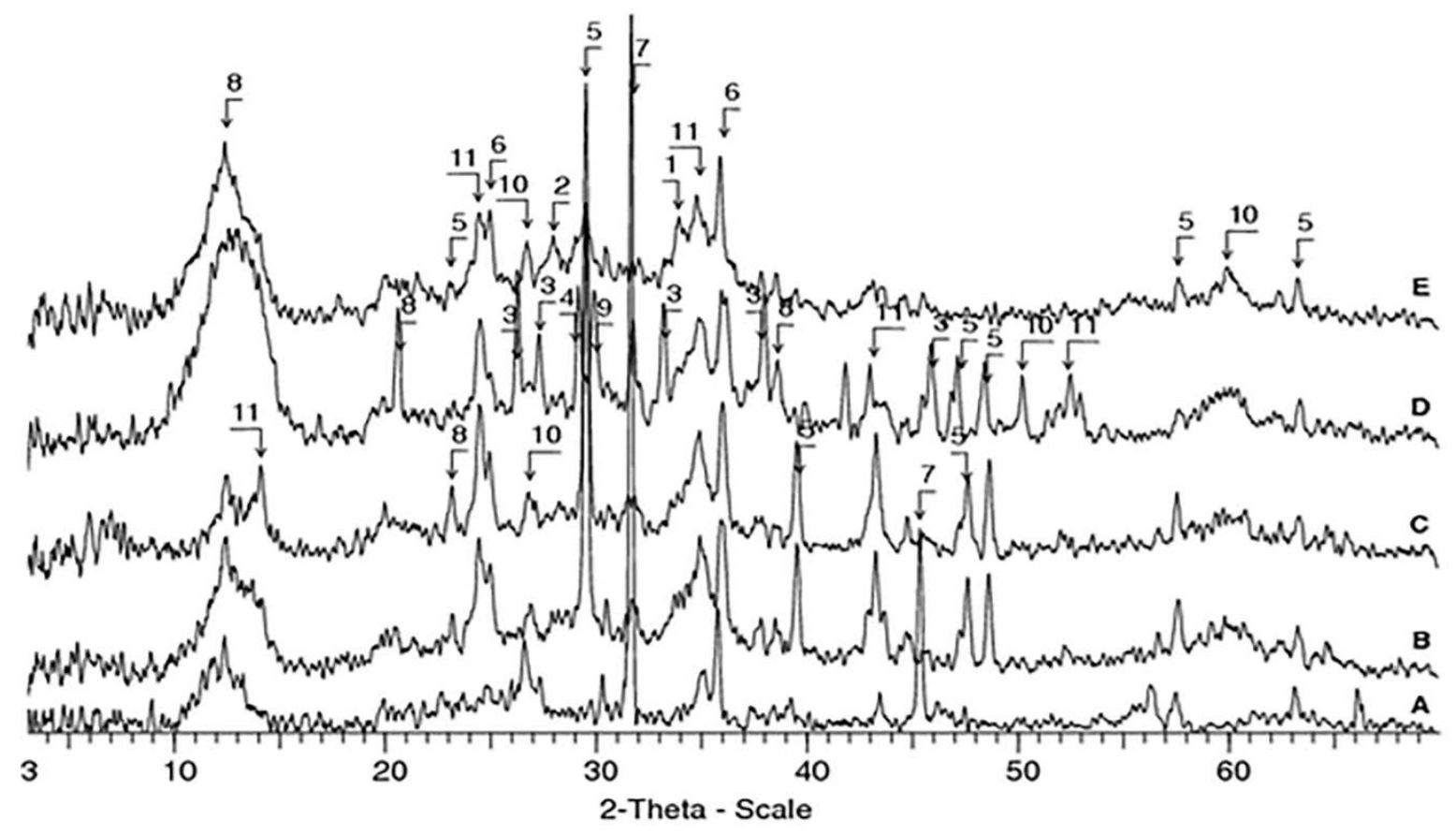

Fig. 13. XRD analysis of geopolymers with FNS under various conditions (A: $60{ }^{\circ} \mathrm{C}-24 \mathrm{~h}-7$ d; B: $60{ }^{\circ} \mathrm{C}-24$ h-28 d; C: $60{ }^{\circ} \mathrm{C}-48$ h-28 d; D: $80{ }^{\circ} \mathrm{C}-48$ h-28 d; 1: Kaolinite, 2:

Maghemite, 3: Magnetite, 4: Quartz, 5: Sodalite) [Komnitsas et al., 2007].

From the above discussion, it can be seen that FNS can be a viable supplementary material in fly ash or metakaolin based geopolymer mixtures. However, there is a debate among the researchers about the role of MgO in geopolymerisation. Yang et al. (2014) and Zhang et al. (2017) reported that MgO participated in hydration reaction, whereas Komnitsas et al. (2007, 2009, 2013) argued that magnesium acted as chemically inert in FNS based mixtures. It also depends on the source of the FNS. Therefore, FNS from a new source has to be thoroughly investigated before its application as a geopolymer precursor.

\section{Environmental effects}

Though the utilization of industrial by-products as binder or aggregate in concrete brings several advantages, their effects on the surrounding environment due to possible leaching of heavy metals into the groundwater or soil needs to be investigated (Hillier et al., 
1999; Marion et al., 2005; Srivastava et al., 2008). Marion et al. (2005) conducted a comparative study in order to identify the leaching of heavy metal from concrete containing blast furnace slag as SCM and porphyry as manufactured aggregate. The authors found that heavy metals released were negligible and well below the regularity limits as per United States Environmental Protection Agency (USEPA, 2009). Similarly, Li et al. (2012) found that leaching of toxic metals from concrete mixed with municipal solid waste incineration bottom ash were below the recommended limits. Manso et al. (2006) conducted a study on EAF slag where, it was used as both binder as well as aggregate in concrete. The authors observed that the leaching of toxic metals were well below the regularity limits in both cases. However, the leaching of heavy metals from the concrete containing EAF slag as a binder were higher as compared to concrete with EAF slag aggregates due to higher cloistering effect. Furthermore, Motz and Geiseler (2001) concluded that the leaching of heavy metals from concrete with steel slag aggregate was negligible and environmentally safe for commercial applications. Besides, the application of pozzolanic materials such as fly ash and silica fume can play a vital role to reduce the leaching of manufactured aggregate by stabilizing the toxic chemicals in pore solution (Yousuf et al., 1995).

It can be seen from Table 1 that FNS contains some heavy metals such as $\mathrm{Cr}$, Ni and Co. Therefore, it is necessary to assess the leaching properties of FNS as an aggregate or binder. FNS has been used in landfill applications in Korea. Kang et al. (2014) examined the soil from different locations where FNS was used as a landfill material. The authors conducted an investigation to determine the number of heavy metals which can be possibly leached out from FNS. This experimental study revealed that though the $\mathrm{pH}$ of the soil was higher than silt, leaching of heavy metals were well below the allowable limits recommended by the United States Environmental Protection Agency (USEPA, 2009). In addition, Saha and Sarker (2017c) conducted a tank leaching study on the concrete samples with full and partial replacement of sand by FNS fine aggregate. The authors collected the leachate after 64 days immersion of the specimens and carried out the chemical analysis to determine the heavy metals in the leachate. The water volume was five times of the concrete volume in their study. The results showed that leaching of heavy metals increased with the increase of FNS content; however, the amount did not exceed the regulatory limits according to the standards (USEPA, 2009). Katsiotis et al. (2015) evaluated the leaching phenomena by tank diffusion in FNS blended concrete according to NEN 7375 (2004). The authors reported that the leaching of heavy metals were within the toxicity limits. On the other hand, geopolymer samples were reported as less susceptible to leaching of heavy metals in the surrounding environment due to low porosity. According to Komnitsas et al. (2013), FNS geopolymers encapsulated the heavy metals such as $\mathrm{Pb}, \mathrm{Cu}, \mathrm{Cr}$ and Ni. Therefore, heavy metals could not leach out from the concrete and maintained the structural integrity. In addition, Fidancevska et al. (2007) pointed out that heavy metals in FNS aggregate are chemically inert. Similarly, Demotica et al., 2012 concluded that toxicity of FNS was less than the maximum allowable concentrations by the standard (USEPA, 2009) and FNS is classified as a non-hazardous material. Recently, Huang et al. 2017 stated that leaching toxicity of $\mathrm{Cr}$ in the case of the mortar containing 30\% FNS powder is rather low $(<0.2 \mathrm{mg} / \mathrm{L})$, which meets the standard GB 30760 (2014). However, Tangahu et al. (2015) found that the concentration of $\mathrm{Cr}$ in FNS from reclamation area exceeded the quality standard in toxicity characteristic leaching procedure (TCLP) based on Indonesia’s government regulation.

From the above discussion, FNS was generally shown to be an environmentally friendly construction material. Its application as a binder or aggregate in concrete and geopolymer exhibited very low leaching of heavy metal. Therefore, this slag can be used in construction practice without any harmful impact on the environment. 


\section{Limitations and further research}

From the above discussion, it is apparent that FNS is an environmentally friendly construction material and its use will reduce the waste management cost of the nickel industries. However, the use of FNS so far has been very limited and is mainly remained in land filling with some use in concrete productions (2017c). There is some notable research work carried out using this material as an aggregate in concrete around 1990 and eventually, this material has been added to the Japanese Industrial Standards (JIS) in 1994 (JSCE, 1994). However, Tomosawa et al. (1997) noticed that this slag is alkali-silica reactive and suggested that the use of low alkali cement or blast furnace slag or fly ash as a supplementary binder to prevent the resulting expansion. Consequently, alkali-silica reactivity is a hindrance to the use wide application of FNS as fine agregate in concrete. The concrete manufacturers are reluctant to use an alkali-silica reactive aggregate. On the other hand, the application fly ash is a wellestablished ASR mitigation technique. It is also noted that published research related to ASR of FNS are insufficient. Choi and Choi (2015) and Saha and Sarker (2016) used accelerated mortar bar test to assess the reactivity of this aggregate under aggressive environment. Therefore, there is a scope to evaluate the long-term ASR performance of FNS aggregates in concrete. Shehata and Thomas (2000) used 18 different types of fly ash with reactive siliceous limestone (Spratt) to evaluate the ASR for two years. In their study, class F fly ash was was found to be more effective to mitigate the ASR as compared to class C fly ash. The continuation of their study indicated that $25 \%$ or $40 \%$ cement replacement by Class $\mathrm{F}$ fly ash was effective to mitigate the deleterious ASR expansion after 18 years of field exposure; however, control concrete with reactive aggregate suffered from excessive expansion and cracking (Thomas et al., 2011). The reactivity of different aggregates can be different, which mainly depends on its mineral composition. Therefore, an experimental study to evaluate ASR of concrete containing FNS aggregate with various proportions of class $\mathrm{F}$ fly ash needs to be conducted. Such test results will concrete manufacturers with detailed knowledge on the mitigation of potential ASR of FNS aggregates in concrete. Although ASTM C1293 (2015) suggests conducting the ASR experiment for a duration of two years, a longer testing period of 5 to 10 years will be highly efficient to identify any slow reactivity phenomena of FNS aggregate combined with fly ash. Besides, an experimental study can be conducted using ground FNS (after grinding as cement substitution) as ASR mitigation technique in FNS aggregate concrete or mortar.

The presence of high percentage of magnesium in FNS is hindering its application as a SCM. The chemical analysis of FNS indicates the presence MgO it is about 30\% (Table 1). It has been well established that, presence of excessive MgO can lead to deleterious expansion after 2-5 years of curing due to the hydration reaction of $\mathrm{MgO}(\mathrm{Du}, 2005)$. The maximum allowable limit of $\mathrm{MgO}$ is $15 \%$ in a binder according to AS 3582.2 standard (2016). However, Rahman et al. (2017) reported that the MgO present in FNS aggregate is in a crystal form known as forsterite, which is does not take part in reactions in Portland cement systems. Komnitsas et al. (2007, 2009, 2013) also reported the similar statement for FNS based geopolymers. However, Yang et al. (2014) and Zhang et al. (2017) stated that the MgO present in FNS is not chemically inert based on hydration reaction product in geopolymer concrete. Moreover, it can be concluded that the variation in experimental results between the researchers is due to the different sources and manufacturing process of FNS and the differences in use. Therefore, a detailed investigation is needed in order to understand FNS as a binder from any particular source in order to evaluate the crystal structure of magnesia and its effect on the durability properties of FNS concrete. Besides, 20\% replacement of binder by FNS in control concrete or fly ash/metakaolin based geopolymer concrete will keep the MgO content below $10 \%$, which is acceptable as per AS 3582.2 standard (2016). The FNS slag has not been adopted 
widely due to the lack of extensive research on the durability properties of FNS blended concrete.

Recently, the application of FNS has been studied extensively in geopolymers. However, hydration reactions associated with geopolymer are yet to be completely understood, as it has issues regarding volume stability (Zuhua et al., 2009; Chanh et al., 2008; Zhang et al., 2009). Moreover, further research is needed to identify the fresh and durability properties of FNS blended cement concrete as well as geopolymer concrete.

\section{Conclusions}

The following conclusions can be drawn based on the conducted review study:

- The use of FNS reduces the workability of the concrete. Furthermore, the bleeding increases slightly in presence of high-density FNS aggregate.

- The utilization of FNS up to $50 \%$ replacement of natural sand improves the mechanical properties such as compressive strength, modulus of elasticity, tensile strength and flexural strength.

- The durability properties of FNS concrete such as air permeability and carbonation similar to those of conventional concrete. However, there is a dispute among the researchers about the freeze and thaw resistance of FNS due to the difference in the FNS properties. Moreover, drying shrinkage is higher in FNS concrete.

- The potential ASR expansion of FNS aggregate is an important aspect that needs to be considered in mix designs. The presence of amorphous silica in water-cooled FNS aggregate may cause ASR expansion. Use of SCMs such as fly ash and blast furnace slag as partial cement replacement is an effective way to mitigate the potential ASR expansion of FNS fine aggregate.

- FNS is a suitable alternative to natural aggregates for pavement construction.

- The MgO present in FNS is in a crystalline structure known as forsterite, which is highly stable in hydration reactions both in OPC concrete and geopolymer concrete.

- $\quad$ FNS shows satisfactory performance as a binder in both OPC concrete and geopolymer. In fly ash based geopolymer, the use of $20 \%$ FNS exhibits higher compressive strength than the reference concrete.

- There is no negative impact on the environment due to the utilization of FNS in the concrete industry.

- Finally, the utilization of FNS as aggregate or supplementary binder will be a good step towards sustainable infrastructure development.

\section{Acknowledgements}

This research was funded and supported by SLN, New Caledonia.

\section{References}

Achal, V., Pan, X., Özyurt, N., 2011. Improved strength and durability of fly ash-amended concrete by microbial calcite precipitation. Eco. Engg. 37(4), 554-9. https://doi.org/10.1016/j.ecoleng.2010.11.009.

Aggarwal, P., Aggarwal, Y., Gupta, S.M., 2007. Effect of bottom ash as replacement of fine aggregates in concrete. Asian journal of civil engineering (building and housing). 8(1), 49-62.

Ahmedzade, P., Sengoz, B., 2009. Evaluation of steel slag coarse aggregate in hot mix asphalt concrete. J. Hazar. Mater. 165, 300-305. https://doi.org/10.1016/j.jhazmat.2008.09.105 
Ameri, M., Behnood, A., Laboratory studies to investigate the properties of CIR mixes containing steel slag as a substitute for virgin aggregates. Cons. Build. Mater. 26 (2012) 475-480. https://doi.org/10.1016/j.conbuildmat.2011.06.047

Ameri, M., Hesami, S., Goli, H., 2013. Laboratory evaluation of warm mix asphalt mixtures containing electric arc furnace (EAF) steel slag. Cons. Build. Mater. 49, 611-617. https://doi.org/10.1016/j.conbuildmat.2013.08.034

Andrade, L.B., Rocha, J.C., Cheriaf, M., 2009. Influence of coal bottom ash as fine aggregate on fresh properties of concrete. Cons. Build. Mater. 23(2), 609-14. https://doi.org/10.1016/j.conbuildmat.2008.05.003

AS 1012.10, 2014. Determination of Indirect Tensile Strength of Concrete Cylinders ('Brazil' or Splitting Test). www.siaglobal.com

AS 1012.17, 1997. Methods of Testing Concrete - Determination of the Static Chord Modulus of Elasticity and Poisson's Ratio of Concrete Specimens. www.siaglobal.com

AS 1012.3.1, 2014. Determination of Properties Related to the Consistency of Concrete Slump Test. www.siaglobal.com.

AS 3582.2, 2016. Supplementary Cementitious Materials Part 2: Slag-Ground Granulated Blast-Furnace, Standards Australian. https://infostore.saiglobal.com.

ASTM C109 / C109M-16a, 2016. Standard Test Method for Compressive Strength of Hydraulic Cement Mortars (Using 2-in. or [50-mm] Cube Specimens), ASTM International, West Conshohocken, PA. www.astm.org

ASTM C1260, 2014. Standard Test Method for Potential Alkali Reactivity of Aggregates (Mortar-Bar Method), ASTM International, West Conshohocken, PA, 2014, www.astm.org.

ASTM C666, 1992. Standard Test Method for Resistance of Concrete to Rapid Freezing and Thawing, ASTM International, West Conshohocken, PA. www.astm.org ASTM, C. 1293, 2015. Standard Test Method for Determination of Length Change of Concrete Due to Alkali-Silica Reaction, ASTM International, West Conshohocken, Pennsylvania, United States. https://www.astm.org/Standards/C1293.htm

Australasian Slag Association (ASA), 2002. A guide to the use of iron and steel slag in roads, Wollongong, NSW.

Bagampadde U., Wahhab H.I.A., Aiban S.A., 1999. Optimization of steel slag aggregates for bituminous mixes in Saudi Arabia. J. Mater. Civil Engg. 11 () 30-35. https://doi.org/10.1061/(ASCE)0899-1561(1999)11:1(30)

Behnood, A., Ameri, M., 2012. Experimental investigation of stone matrix asphalt mixtures

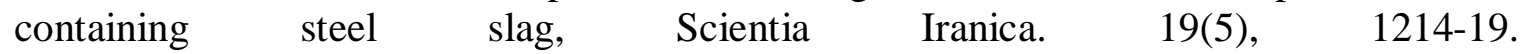
https://doi.org/10.1016/j.scient.2012.07.007

Berndt, M.L., 2009. Properties of sustainable concrete containing fly ash, slag and recycled concrete aggregate. Cons. Build. Mater. 23(7), 2606-13. https://doi.org/10.1016/j.conbuildmat.2009.02.011.

Carvalho, S.Z., Vernilli, F., Almeida, B., Demarco, M., Silva, S.N., 2017. The recycling effect of BOF slag in the portland cement properties. Resour. Conserve. Recycl. 127, 216-220. https://doi.org/10.1016/j.resconrec.2017.08.021

Chanh, N.V., Trung, B.D., Tuan, D.V., 2008. Recent research geopolymer concrete. In The 3rd ACF International Conference-ACF/VCA, Vietnam, pp. 235-41.

Choi, Y.C., Choi, S., 2015. Alkali-silica reactivity of cementitious materials using ferro-nickel slag fine aggregates produced in different cooling conditions, Cons. Build. Mater. 99, 279-87. https://doi.org/10.1016/j.conbuildmat.2015.09.039

Coey, J.M., Skumryev, V., Gallagher, K., 1999. Rare-earth metals: Is gadolinium really ferromagnetic? Nature. 401, 35-36. doi:10.1038/43363. 
Dalvi, A.D., Bacon, W.G., Osborne, R.C., 2004. The past and the future of nickel laterites. PDAC 2004 International Convention, Trade Show \& Investors Exchange, Toronto, Canada, pp1-27. http://citeseerx.ist.psu.edu/viewdoc/download?doi=10.1.1.732.7854\&rep=rep1\&type=p $\underline{\mathrm{df}}$

Das, B., Prakash, S., Reddy, P.S.R., Misra, V.N., 2007. An overview of utilization of slag and sludge from steel industries. Resour. Conserve. Recycl. 50(1), 40-57. https://doi.org/10.1016/j.resconrec.2006.05.008

Davis, J., Bird, J., Finlayson, B., Scott, R., 2000. The management of gravel extraction in alluvial rivers: a case study from the Avon River, southeastern Australia, Physical Geography. 21(2), 133-54. https://doi.org/10.1080/02723646.2000.10642703

Du, C., 2005. A review of magnesium oxide in concrete. Concr. Inter. 27 (12), 45-50.

Emery J.J., 1984. Steel Slag utilization in asphalt mixes, In Canadian Technical Asphalt Association Proceedings, National Slag Association, Canada.

Fidancevska, E., Mangutova, B., Milosevski, D., Milosevski, M., Bossert, J., 2003. Obtaining of dense and highly porous ceramic materials from metallurgical slag. Sci Sinter. 35(2), 85-91. http://www.doiserbia.nb.rs/img/doi/0350-820X/2003/0350-820X0302085F.pdf

Fidancevska, E., Vassilev, V., Milosevski, M., Parvanov, S., Milosevski, D., Aljihmani, L., 2007. Composites based on industrial wastes III. production of composites of Fe-Ni slag and waste glass. J. Uni. Chem. Tech. Metallur. 42(3), 285-90. http://dl.uctm.edu/journal/node/j2007-3/8_Venci_Vasilev_285-290.pdf

GB 30760, 2014. Technical specification for coprocessing of solid waste in cement kiln. National Standards of People's Republic of China. https://www.chinesestandard.net/Default.aspx?PDF-English-ID=GB\%2030760-2014

Geopolymer institute, 2017. Geopolymer cement and Geopolymer Concrete. https://www.geopolymer.org/applications/geopolymer-cement/

Ghods, P., Alizadeh, R., Salehi, M., 2017. Electrical methods and systems for concrete testing, United States patent US 9,638,652. https://www.google.com/patents/US9638652.

Grattan-Bellew, P. E., Mitchell, L. D., Margeson, J., Min, D., 2010. Is alkali-carbonate reaction just a variant of alkali-silica reaction ACR $=$ ASR?. Cement and Concrete Research, 40(4), 556-562.

Hainin, M.R., Rusbintardjo, G., Aziz, M.A.A., Hamim, A., Yusoff, N.I.M., 2013. Laboratory evaluation on steel slag as aggregate replacement in stone masticasphalt mixtures. Jur. Tekn. 65, 13-19. http://dx.doi.org/10.11113/jt.v65.2185

Hainin, M.R., Rusbintardjo, G., Hameed, M.A.S., Hassan, N.A., Yusoff, N.I.M., 2014. Utilisation of steel slag as an aggregate replacement in porous asphalt mixtures. Jur. Tekn. 69, 67-73. DOI: 10.11113/jt.v69.2529.

Hainin, M.R., Yusoff, N.I.M., Sabri, M.F.M., Aziz, M.A.A., Hameed, M.A.S., Reshi, W.F., 2012. Steel slag as an aggregate replacement in malaysian hot mix asphalt. ISRN Civil Engg. 2012, 1-5. http://dx.doi.org/10.5402/2012/459016.

Hardjito, D., Wallah, S.E., Sumajouw, D.M., Rangan, B.V., 2004. On the development of fly ash-based geopolymer concrete. Mater. J. 101(6), 467-72. https://www.concrete.org/publications/internationalconcreteabstractsportal.aspx?m=detail S\&ID=13485

Hardjito, D., Wallah, S.E., Sumajouw, D.M.J., Rangan, B.V., 2005. Fly ash-based geopolymer concrete. Aus. J. Struct. Engg. 6(1), 77-86.

Hillier, S.R., Sangha, C.M., Plunkett, B.A., Walden, P.J., 1999. Long-term leaching of toxic trace metals from Portland cement concrete. Cem. Concr. Res. 29(4), 515-521. https://doi.org/10.1016/S0008-8846(98)00200-2 
Hou, X., Struble, L.J., Kirkpatrick, R.J., 2004. Formation of ASR gel and the roles of CSH and portlandite. Cem. Concr. Res. 34(9), 1683-96.

https://doi.org/10.1016/j.cemconres.2004.03.026

$\mathrm{Hu}$, J., Wang, K., 2005. Effects of aggregate on flow properties of mortar, In Mid-Continent Transportation Research Symposium, Ames, Iowa, pp. 8.

Huang, Y., Wang, Q., Shi, M., 2017. Characteristics and reactivity of ferronickel slag powder. Cons. Build. Mater. 156, 773-789. https://doi.org/10.1016/j.conbuildmat.2017.09.038

Ismail, Z.Z., Al-Hashmi, E.A., 2008. Use of waste plastic in concrete mixture as aggregate replacement. Waste Manag. 28(11), 2041-7.

https://doi.org/10.1016/j.wasman.2007.08.023

Ichikawa, T., Miura, M., 2007. Modified model of alkali-silica reaction. Cement and Concrete research, 37(9), 1291-1297.

JIS A 1108, 2006. Method of test for compressive strength of concrete. Japanese Standards Association. https://infostore.saiglobal.com/en-au/Standards/JIS-A-1108-2006-773711/

JIS A 1113, 2006. Method of test for splitting tensile strength of concrete. Japanese Standards Association. https://infostore.saiglobal.com/store/details.aspx?ProductID=773716

JIS A 1123, 1997. Method of test for bleeding of concrete. Japanese Standards Association. https://infostore.saiglobal.com/store/details.aspx?ProductID=956225

JIS A 1129-1, 2010. Methods Of Measurement For Length Change Of Mortar And Concrete - Part 1: Method With Comparator. https://infostore.saiglobal.com/store/details.aspx?ProductID=1436580

JIS A 1148, 2010. Method of test for splitting tensile strength of concrete. Japanese Standards Association.

https://webdesk.jsa.or.jp/books/W11M0090/index/?bunsyo_id=JIS\%20A\%201148:2010

JMIA, 1991. Research of ferronickel slag fine aggregate for concrete, Japan Mining Industry Association. http://jglobal.jst.go.jp.

JSCE committee, 1994. Guidelines for Construction Using Ferronickel Slag Fine Aggregate Concrete. Concr. Libr. JSCE No. 24. http://www.jsce.or.jp.

Kang S.S., Park K., Kim D., 2014. Potential Soil Contamination in Areas Where Ferronickel Slag Is Used for Reclamation Work. Materials. 7(10), 7157-72. doi:10.3390/ma7107157

Katsiotis, N.S., Tsakiridis, P.E., Velissariou, D., Katsiotis, M.S., Alhassan, S.M., Beazi, M., 2015. Utilization of ferronickel slag as additive in Portland cement: a hydration leaching study. Waste Biomass Valor. 6(2), 177-89. https://doi.org/10.1007/s12649-015-9346-7

Klein, C., Hurlbut, C.S., Dana, J.D. 1998. Manual of mineralogy. Twenty first ed. Wiley, New Jersey, United States, pp. 373-375.

Komnitsas, K, Zaharaki, D., Bartzas, G., 2013. Effect of sulphate and nitrate anions on heavy metal immobilisation in ferronickel slag geopolymers. Appl. Clay Sci. 73, 103-9. https://doi.org/10.1016/j.clay.2012.09.018

Komnitsas, K., Zaharaki, D., Perdikatsis, V., 2007. Geopolymerisation of low calcium ferronickel slags. J. Mater. Sci. 42(9), 3073-82. https://doi.org/10.1007/s10853-0060529-2

Komnitsas, K., Zaharaki, D., Perdikatsis, V., 2009. Effect of synthesis parameters on the compressive strength of low-calcium ferronickel slag inorganic polymers. J. Hazar. Mater. 161(2), 760-8. https://doi.org/10.1016/j.jhazmat.2008.04.055

Kosanović, C., Stubičar, N., Tomašić, N., Bermanec, V., Stubičar, M. 2005. Synthesis of a forsterite powder by combined ball milling and thermal treatment. J. Alloys Comp. 389(1), 306-9. https://doi.org/10.1016/j.jallcom.2004.08.015

Krayushkina, K., Prentkovskis, O., Bieliatynskyi, A., Junevičius, R., 2012. Use of steel slags in automobile road construction. Transport. 27(2), 129-37. https://doi.org/10.3846/16484142.2012.690093 
Kuroda, M., Watanabe, T., Terashi, N., 2000. Increase of bond strength at interfacial transition zone by the use of fly ash. Cem. Concr. Res. 30(2), 253-8. https://doi.org/10.1016/S00088846(99)00241-0

Lee, K.M., Lee, H.K., Lee, S.H., Kim, G.Y. 2006. Autogenous shrinkage of concrete containing granulated blast-furnace slag. Cem. Concr. Res. 36(7), 1279-85. https://doi.org/10.1016/j.cemconres.2006.01.005.

Li, X.G., Lv, Y., Ma, B.G., Chen, Q.B., Yin, X.B., Jian, S.W., 2012. Utilization of municipal solid waste incineration bottom ash in blended cement. J. Clean. Produc. 32, 96-100. https://doi.org/10.1016/j.jclepro.2012.03.038

Liu, P.C., 2009. Damage to concrete structures in a marine environment. Mater. Struct. 24(4), 302-7. https://doi.org/10.1007/BF02472086

Loh, Y.R., Sujan, D., Rahman, M.E., Das, C.A., 2013. Sugarcane bagasse-The future composite material: A literature review. Resour. Conserve. Recycl. 75, 14-22. https://doi.org/10.1016/j.resconrec.2013.03.002

Maghsoudlou, M.S., Ebadzadeh, T., Sharafi, Z., Arabi, M., Zahabi, K.R. 2016. Synthesis and sintering of nano-sized forsterite prepared by short mechanochemical activation process. J. Alloys Comp. 678, 290-6. https://doi.org/10.1016/j.jallcom.2016.02.020

Manso, J.M., Polanco, J.A., Losanez, M., González, J.J., 2006. Durability of concrete made with EAF slag as aggregate. Cem. Concr. Compos. 28(6), 528-34. https://doi.org/10.1016/j.cemconcomp.2006.02.008

Maragkos, I., Giannopoulou, I.P., Panias, D., 2009. Synthesis of ferronickel slag-based geopolymers. $\quad$ Minerals Engg. 22(2), 196-203. https://doi.org/10.1016/j.mineng.2008.07.003

Marion, A.M., Laneve, M.D., Grauw, A.D., 2005. Study of the leaching behaviour of paving concretes: quantification of heavy metal content in leachates issued from tank test using demineralized water. Cem. Concr. Res. 35(5), 951-957. https://doi.org/10.1016/j.cemconres.2004.06.014

Masterbuilder, 2014. River Sand Substitutes - An Overview. Masterbuilder, India's premier construction magazine. https://www.masterbuilder.co.in/river-sand-substitutes-overview/.

Mehata, P.K., Monteiro, P.J.M., 2006. Concrete: microstructure, properties, and materials. third ed. McGraw-Hill Publishing, New York. https://www.bookdepository.com/ConcreteMicrostructure-Properties-Materials-P-Kumar-Mehta/9780071797870

Mo, L., Deng, M., Tang, M., Al-Tabbaa, A., 2014. MgO expansive cement and concrete in China: Past, present and future. Cem. Concr. Res. 57, 1-2. https://doi.org/10.1016/j.cemconres.2013.12.007

Molugaram, K., Jaya Shanker, S., Ramesh, A., 2014. A Study on Influence of Shape of Aggregate on Strength and Quality of Concrete for Buildings and Pavements, Adv. Mater. Res. 941-944, 776-779. 10.4028/www.scientific.net/AMR.941-944.776

Motz H., J. Geiseler, 2001. Products of steel slags an opportunity to save natural resources. Waste Manage. 21(3), 285-293. https://doi.org/10.1016/S0956-053X(00)00102-1

Moser, R. D., Jayapalan, A. R., Garas, V. Y., \& Kurtis, K. E., 2010. Assessment of binary and ternary blends of metakaolin and Class $\mathrm{C}$ fly ash for alkali-silica reaction mitigation in concrete. Cement and Concrete Research, 40(12), 1664-1672. https://doi.org/10.1016/j.cemconres.2010.08.006

Nagataki, S., Ujike, I., 1988. Effect of heating condition on air permeability of concrete at elevated temperature, Trans. Jap. Concr. Inst. 10, 147-154. https://ci.nii.ac.jp/naid/110009743015/en/

NEN 7375. 2004. Leaching characteristics determination of the leaching of inorganic components from moulded or monolithic materials with the diffusion test-solid earthy and stony materials, Netherlands Normalisation Institute Standard, Delft. https://www.iso.org 
Oluwasola E.A., Hainin M.R., Aziz M.M.A., 2015. Evaluation of rutting potential and skid resistance of hot mix asphalt incorporating electric arc furnace steel slag and copper mine tailing. Ind. J. Engg. Mater. Sci. 22, 550-558. http://nopr.niscair.res.in/handle/123456789/33438

Oluwasola, E.A., Hainin, M.R., Aziz, M.M.A., 2015. Evaluation of asphalt mixtures incorporating electric arc furnace steel slag and copper mine tailings for road construction. Transp. Geotec. 2, 47-55. https://doi.org/10.1016/j.trgeo.2014.09.004

Padmalal, D., Maya, K., Sreebha, S., Sreeja, R., 2008. Environmental effects of river sand mining: a case from the river catchments of Vembanad lake, Southwest coast of India. Enviro. Geo. 54(4), 879-89. https://doi.org/10.1007/s00254-007-0870-z

Pang, B., Zhou, Z., Hou, P., Du, P., Zhang, L., Xu, H., 2016. Autogenous and engineered healing mechanisms of carbonated steel slag aggregate in concrete. Cons. Build. Mater. Mar 15(107), 191-202. https://doi.org/10.1016/j.conbuildmat.2015.12.191.

Pasetto, M., Baldo, N., 2006. Electric arc furnace steel slags in high performance asphalt mixes:

A laboratory characterisation. In TMS Fall Extraction and Processing Division: Sohn International Symposium, San Diego, pp. 443-450.

Pofale, A.D., Deo, S.V., 2010. Comparative long term study of concrete mix design procedure for fine aggregate replacement with fly ash by minimum voids method and maximum density method. KSCE J. Civil Engg. 14(5), 759-64. https://doi.org/10.1007/s12205010-0911-0

Preciso, E., Salemi, E., Billi, P., 2012. Land use changes, torrent control works and sediment mining: effects on channel morphology and sediment flux, case study of the Reno River (Northern Italy). Hydro. Proc. 26(8), 1134-48. doi: 10.1002/hyp.8202.

Qasrawi, H., Shalabi, F., Asi, I., 2009. Use of low CaO unprocessed steel slag in concrete as fine aggregate. Cons. Build. Mater. 23(2), 1118-1125. https://doi.org/10.1016/j.conbuildmat.2008.06.003

Rahman, M.A., Sarker, P.K., Shaikh, F.U., A.K. Saha. 2017. Soundness and compressive strength of Portland cement blended with ground granulated ferronickel slag. Cons. Build. Mater. 140, 194-202. https://doi.org/10.1016/j.conbuildmat.2017.02.023.

Rodriguez, Á., Manso, J.M., Aragón, Á., Gonzalez, J.J., 2009. Strength and workability of masonry mortars manufactured with ladle furnace slag. Resour. Conserve. Recycl. 53(11), 645-51. https://doi.org/10.1016/j.resconrec.2009.04.015

Saha A.K., Sarker, P.K., 2016. Expansion due to alkali-silica reaction of ferronickel slag fine aggregate in OPC and blended cement mortars. Cons. Build. Mater. 123, 135-42. https://doi.org/10.1016/j.conbuildmat.2016.06.144

Saha A.K., Sarker, P.K., 2017b. Durability of mortar incorporating ferronickel slag aggregate and supplementary cementitious materials subjected to wet-dry cycles, Inter. J. Concr. Struc. Mater. In press. https://doi.org/10.1007/s40069-017-0226-3.

Saha, A.K., Sarker, P.K., 2017a. Durability characteristics of concrete using ferronickel slag fine aggregate and fly ash. Magaz Concr. Res. In press. https://doi.org/10.1680/jmacr.17.00260.

Saha, A.K., Sarker, P.K., 2017c. Sustainable use of ferronickel slag fine aggregate and fly ash in structural concrete: Mechanical properties and leaching study, J. Clean. Produc. 162, 438-48. https://doi.org/10.1016/j.jclepro.2017.06.035

Saha, A.K., Sarker, P.K., 2017d. Compressive strength of mortar containing ferronickel slag as replacement of natural sand. Proc. Engg. 171, 689-94. https://doi.org/10.1016/j.proeng.2017.01.410

Sakkas, K., Nomikos, P., Sofianos, A., Panias, D., 2014. Utilisation of FeNi-slag for the production of inorganic polymeric materials for construction or for passive fire protection. Waste Biomass Valor. 5(3), 403-10. https://doi.org/10.1007/s12649-013-9278-z 
Sakoi, Y., Aba, M., Tsukinaga, Y., Nagataki, S., 2013. Properties of concrete used in ferronickel slag aggregate. In Proceedings of the 3rd International Conference on Sustainable Construction Materials and Technologies. Tokyo, Japan, pp. 1-6.

Santamarina, J.C., 2008Flow test evaluation.

https://smartech.gatech.edu/bitstream/handle/1853/23048/e-20-k79 9124.pdf.

Sato T., Watanabe, K., Ota, A., Aba, M., Sakoi, Y., 2011. Influence of excessive bleeding on frost susceptibility of concrete incorporating ferronickel slag as aggregates. In 36th Conference on Our World in Concrete \& Structures. Singapore.

Shafaatian, S.M., Akhavan, A., Maraghechi, H., Rajabipour, F., 2013. How does fly ash mitigate alkali-silica reaction (ASR) in accelerated mortar bar test (ASTM C1567)? Cem. Concr. Compos. 37, 143-53 https://doi.org/10.1016/j.cemconcomp.2012.11.004

Shehata, M.H., Thomas, M.D., 2000. The effect of fly ash composition on the expansion of concrete due to alkali-silica reaction. Cem. Concr. Res. 30(7), 1063-72. https://doi.org/10.1016/S0008-8846(00)00283-0

Shehata, M.H., Thomas, M.D., Bleszynski, R.F., 1999. The effects of fly ash composition on the chemistry of pore solution in hydrated cement pastes. Cem. Concr. Res. 29(12), 191520. https://doi.org/10.1016/S0008-8846(99)00190-8

Shi, C., 2004. Effect of mixing proportions of concrete on its electrical conductivity and the rapid chloride permeability test (ASTM C1202 or ASSHTO T277) results. Cem. Concr. Res. 34(3), 537-45. https://doi.org/10.1016/j.cemconres.2003.09.007

Shi, C., Meyer, C., Behnood, A., 2008. Utilization of copper slag in cement and concrete. Resour. Conserve. $\quad$ Recycl. https://doi.org/10.1016/j.resconrec.2008.06.008

Shi, C., Qian, J., 2000. High performance cementing materials from industrial slags-a review. Resour. Conserve. Recycl. 29(3), 195-207. https://doi.org/10.1016/S0921-3449(99)00060$\underline{9}$

Shoya, M., Sugita, S., Tsukinaga, T., Aba, M., 1999. Tokuhasi, K., Properties of selfcompacting concrete with slag fine aggregates, In Exploiting Wastes in Concrete, University of Dundee, Scotland. pp. 121-130.

Skaf, M., Manso, J.M., Aragón, Á., Fuente-Alonso, J.A., Ortega-López, V., 2017. EAF slag in asphalt mixes: A brief review of its possible re-use. Resour. Conserv. Recycl. 120, 176-85. https://doi.org/10.1016/j.resconrec.2016.12.009

Srivastava, S., Chaudhary, R., Khale, D., 2008. Influence of $\mathrm{pH}$, curing time and environmental stress on the immobilization of hazardous waste using activated fly ash. J. Hazard. Mater. 153(3), 1103-9. DOI:10.1016/j.jhazmat.2007.09.065

Swamy, R.N., 1992, Testing for alkali-silica reaction, in: R.N. Swamy (Ed.), The Alkali-Silica Reaction in Concrete, Blackie, Glasgow and London, and Van Nostrand-Reinhold, New York, pp. 54-95.

Tangahu1, B.V., Warmadewanthi1, I., Saptarini, D., Pudjiastuti, L., Tardan1, M. A. M., Luqman1, A., 2015. Ferronickel Slag Performance from Reclamation Area in Pomalaa, Southeast Sulawesi, Indonesia. Adv. Chem. Eng. Sci. 5, 408-412. http://dx.doi.org/10.4236/aces.2015.53041

Thomas, M., Dunster A., Nixon, P., Blackwell, B., 2011. Effect of fly ash on the expansion of concrete due to alkali-silica reaction-Exposure site studies. Cem. Concr. Compos. 33(3), 359-67. https://doi.org/10.1016/j.cemconcomp.2010.11.006

Togawa, K., Shoya, M., Kokubu, K., 1996. Characteristics of bleeding, freeze-thaw resistance and watertightness of concrete with ferro-nickel slag fine aggregates. J. Socie. Materials Sci, Japan. 45(1), 101-9. https://doi.org/10.2472/jsms.45.101

Tomosawa, F., Nagataki, S., Kajiwara, T., Yokoyama, M., 1997. Alkali-aggregate Reactivity of Ferronickel-Slag Aggregate Concrete. ACI Special Publication. 170, 1591-602. 
https://www.concrete.org/publications/internationalconcreteabstractsportal/m/details/id/6 $\underline{893}$

US EPA (United States Environmental Protection Agency), 2009. Hazardous waste characteristics. $\quad$ https://www.epa.gov/sites/production/files/2016-01/documents/hwchar.pdf/.

US-GS (United States Geological Survey), 2009. Mineral Commodity Summaries. https://minerals.usgs.gov/minerals/pubs/mcs/2009/mcs2009.pdf

Vayghan A.G., Rajabipour, F., Rosenberger, J.L., 2016. Composition-rheology relationships in alkali-silica reaction gels and the impact on the Gel's deleterious behavior. Cem. Concr. Res. 83, 45-56. https://doi.org/10.1016/j.cemconres.2016.01.011

Wang, G., Thompson, R., 2011. Slag use in highway construction-the philosophy and technology of its utilization, Inter. J. Pave. Res. Tech. 4(2), 97-103. http://www.ijprt.org.tw/mailweb/files/sample/V4N2_97-103.pdf

Wang, G., Thompson, R., Wang, Y., 2011. Hot-mix asphalt that contains nickel slag aggregate: laboratory evaluation of use in highway construction. Trans. Res. Record: J. Trans. Res. Board. 2208, 1-8. https://doi.org/10.3141/2208-01

Wang, S., Llamazos, E., Baxter, L., Fonseca, F., 2008a. Durability of biomass fly ash concrete: freezing and thawing and rapid chloride permeability tests. Fuel. 87(3), 359-64. https://doi.org/10.1016/j.fuel.2007.05.027.

Wang, S., Miller, A., Llamazos, E., Fonseca, F., Baxter, L., 2008b. Biomass fly ash in concrete: mixture proportioning and mechanical properties. Fuel. 87(3), 365-71. https://doi.org/10.1016/j.fuel.2007.05.026.

Wu, K.R., Chen, B., Yao, W., Zhang, D., 2001. Effect of coarse aggregate type on mechanical properties of high-performance concrete. Cem Concr Res, 31 (2001), 14211425. https://doi.org/10.1016/S0008-8846(01)00588-9.

Wu, S., Xue, Y., Ye, Q., Chen, Y., 2007. Utilization of steel slag as aggregates for stone mastic asphalt (SMA) mixtures. Build. Environ. 42, 2580-2585. https://doi.org/10.1016/j.buildenv.2006.06.008

Yang, T., Yao, X., Zhang, Z., 2014. Geopolymer prepared with high-magnesium nickel slag: characterization of properties and microstructure. Cons. Build. Mater. 59, 188-94. https://doi.org/10.1016/j.conbuildmat.2014.01.038

Yasuaki, M., Hiromichi, T., Yoshio, O., Kenji, M., 1989, A study on cooling condition and structure of ferronickel slag: cooling condition for prevention of alkali-aggregate reaction. Shigen-to-Sozai. 105(14), 1067-1071. https://doi.org/10.2473/shigentosozai.105.1067

Yeau, K.Y., Kim, E.K., 2005. An experimental study on corrosion resistance of concrete with ground granulate blast-furnace slag. Cem. Concr. Res. 35(7), 1391-9. https://doi.org/10.1016/j.cemconres.2004.11.010

Yi, H., Xu, G., Cheng, H., Wang, J., Wan, Y., Chen, H., 2012, An overview of utilization of steel slag. $\quad$ Proc. Environ. Sci. 16, 791-801. https://doi.org/10.1016/j.proenv.2012.10.108

Yousuf, M., Mollah, A., Vempati, R.K., Lin, T.C., Cocke, D.L., 1995. The interfacial chemistry of solidification/stabilization of metals in cement and pozzolanic material systems. Waste Manage. 15(2), 137-48. https://doi.org/10.1016/0956-053X(95)00013-P

Yüksel, İ., Bilir, T., Özkan, Ö., 2007. Durability of concrete incorporating non-ground blast furnace slag and bottom ash as fine aggregate. Build. Environ. 42(7), 2651-9. https://doi.org/10.1016/j.buildenv.2006.07.003

Zhang, Z., Zhu, Y., Yang, T., Li, L., Zhu, H., Wang, H., 2017. Conversion of local industrial wastes into greener cement through geopolymer technology: a case study of high- 
magnesium nickel slag. J. Clean. Produc. 141, 463-71. https://doi.org/10.1016/j.jclepro.2016.09.147

Zhang, Z.H., Yao, X., Zhu, H.J., Hua, S.D., Chen, Y., 2009. Preparation and mechanical properties of polypropylene fiber reinforced calcined kaolin-fly ash based geopolymer. J. Centr. South Uni. Tech. 16(1), 49-52. https://doi.org/10.1007/s11771-009-0008-4

Zheng, L., Wang, W., Shi, Y., 2010.The effects of alkaline dosage and Si/Al ratio on the immobilization of heavy metals in municipal solid waste incineration fly ash-based geopolymer.

Chemosphere, 79(6),

665-71. https://doi.org/10.1016/j.chemosphere.2010.02.018

Ziari, H., Nowbakht, S., Rezaei, S., Mahboob, A., 2015. Laboratory investigation of fatigue characteristics of asphalt mixtures with steel slag aggregates. Adv. Mater. Sci. Engg. 2015, 1-5. http://dx.doi.org/10.1155/2015/623245

Zuhua, Z., Xiao, Y., Huajun, Z., Yue, C., 2009. Role of water in the synthesis of calcined kaolin-based geopolymer. Appl. Clay Sci. 43(2), 218-23. https://doi.org/10.1016/j.clay.2008.09.003 